\title{
Çin'in Afrika Kriz Bölgelerindeki Dış Politikasının Analizi: Darfur ve Güney Sudan Örnekleri
}

\section{Analysis of the Chinese Foreign Policy on the Crisis Regions in Africa: The Case Studies of Darfur and South Sudan}

\author{
Ragıp Kutay Karaca' ${ }^{1}$ )
}

Müge Yüce ${ }^{2}$ (ㅇ

Öz

Çin dış politikasında son yıllarda karşılıkı ilişkilerin en yüksek ivmeyi kazandığı kıta olarak Afrika ön plana çıkmaktadır. Öyle ki, Çin'in Sahraaltt Afrika'da yürüttüğü dış politikanın ekonomik boyutu Afrika'nın "yeni sömürgecilik" faaliyetlerine maruz bırakııdığı yönünde yorumlar yapılmasına yol açmaktadır. Çin dış politikasının Afrika açıımının temelini oluşturan ve "sömürgecilik" söylemlerine yol açan sebeplerin başında Çin'in bölge ülkeleri ile kurduğu enerji ilişkileri ile ticari ilişkilerin niteliği gelmektedir. Çin tarafindan Sahraalt Afrika ülkelerinin enerji sektörlerine yapılan dev yatırımlar ve Çin lehine fazla veren karşılıkı ticaret, Afrika ülkelerinin Çin'e bağımlı hale gelmelerine yol açmaktadır. Bu tek taraflı bağımlılık durumu, Çin'in Afrika'da alternatif güç ilişkileri kurmaya çalıştı̆ı̆ yönünde bir tehdit algısının oluşmasına zemin hazırlamaktadır. Fakat son yıllarda Çin'in Afrika'daki kriz bölgelerinde üstlenmiş olduğu arabuluculuk rolü ve bu krizlerin çözülmesi için uluslararası örgütlerle kurduğu iş birliği, Çin'e yönelik oluş(turul)an tehdit algısının yeniden yorumlanmasını gerektirmektedir. Nitekim 1990'। yıllara kadar kriz bölgelerinde konuşlandırılacak BM Barışı Koruma Operasyonları'na karşı muhalif tutumundan taviz vermeyen Çin, 2019 itibariyle Afrika'da yürütülen yedi operasyondan beş tanesinde aktif şekilde yer almaktadır. Bu çalışmada Çin'in Sahraalt Afrika'da sürdürdüğü dış politika tarihsel açıdan ele alınmış ve Afrika'nın Çin dış politikasındaki yeri, Darfur ve Güney Sudan kriz bölgelerinde yürütülen BM Barışı Koruma Operasyonları'na verilen destek üzerinden açıklanmaya çalışılııştır.

\section{Anahtar Kelimeler \\ BM Barışı Koruma Operasyonları, Çin, Afrika, Kriz bölgeleri, Dış politika}

\begin{abstract}
Africa, as a continent with which China has intensified its bilateral relations most, has been at the forefront of the Chinese foreign policy in recent years. However, certain economic aspects of the Chinese foreign policy towards Sub-Saharan Africa have been construed by some as a sort of "neo-colonialism". There are mainly differing aspects in China's energy and trade relations with the countries in the region that cause these discourses on "colonialism". The giant investments int the energy sectors of Sub-Saharan Africa countries and the trade-surplus in bilateral trade in favour of China make African countries dependent on China. Owing to this one-sided dependency, there are fears that China is seeking to establish alternative power relations in Africa. Having said that, Chinese efforts for mediation in crisis areas in Africa and its cooperation with international organizations for the resolution of conflicts require a re-assessment of these threats perceived from or constituted against China. For instance, although China opposed the deployment of UN Peacekeeping Operations in the crisis areas in 1990s, it has been actively taking part in five of seven operations as of 2019. In this article, a historical evaluation of the Chinese foreign policy towards Sub-Saharan Africa has been made, and the place of Africa in the Chinese policy has been explained with reference to support given to the UN Peacekeeping Operations in Darfur and South Sudan crisis areas.
\end{abstract}

\section{Keywords}

UN Peacekeeping Operations, China, Africa, Crisis regions, Foreign policy

1 Ragıp Kutay Karaca (Prof. Dr.), İstanbul Aydın Üniversitesi, İktisadi ve İdari Bilimler Fakültesi, Siyaset Bilimi ve Uluslararası îlişkiler Bölümü (İngilizce), İstanbul, Türkiye. E-posta: ragipkaraca@aydin.edu.tr ORCID: 0000-0002-7418-3466

2 Sorumlu Yazar: Müge Yüce (Arş. Gör. Dr.), Atatürk Üniversitesi, İktisadi ve İdari Bilimler Fakültesi, Uluslararası İlişkiler Bölümü, Erzurum, Türkiye. E-posta: muge.yuce@atauni.edu.tr ORCID: 0000-0002-7593-6060

Attf: Karaca R. K. ve Yuce M. (2020). Çin'in Afrika kriz bölgelerindeki dış politikasının analizi: Darfur ve Güney Sudan örnekleri. SiYASAL: Journal of Political Sciences, 29(1), 1-32. http://doi.org/10.26650/siyasal.2020.29.1.0022 


\section{Extended Summary}

Africa, as a continent with which China has intensified its bilateral relations most, has been at the forefront of the Chinese foreign policy in recent years. However, certain economic aspects of the Chinese foreign policy towards Sub-Saharan Africa have been construed by some as a sort of "neo-colonialism". There are mainly differing aspects in China's energy and trade relations with the countries in the region that cause these discourses on "colonialism". The giant investments in the energy sectors of Sub-Saharan Africa countries and the trade-surplus in bilateral trade in favour of China make African countries dependent on China. Owing to this one-sided dependency, there are fears that China is seeking to establish alternative power relations in Africa. Having said that, the Chinese efforts for mediation in crisis areas in Africa and its cooperation with international organizations for the resolution of conflicts require a re-assessment of these threats perceived from or constituted against China.

In this article, a historical evaluation of the Chinese foreign policy towards Sub-Saharan Africa has been made, and the place of Africa in the Chinese policy has been explained with reference to support given to the UN Peacekeeping Operations in Darfur and South Sudan crisis areas. Although China opposed the deployment of UN Peacekeeping Operations in the crisis areas in 1990s, it has been actively taking part in five of seven operations as of 2019. Indeed, China's attitude towards the UN Peacekeeping Operations has evolved from abstention to military and financial support. The changing attitude towards UN Peacekeeping Operations has resulted in increased financial support provided by China to UNPKO budget. While China contributed 3.9\% to the UN Peacekeeping Operations budget in 2012, this rate reached $10.3 \%$ as of 2018 .

It is seen that China has an active role in crisis regions in Africa as compared to other regions and contributes the most to the Peacekeeping Operations organized by the UN. For this reason, China's African policy needs to be evaluated from a broad perspective. Beijing supports operations in Africa while it opposes a possible UN Peacekeeping Operation in the Syrian Crisis. At this stage, the support given to the operations in African crisis regions is remarkable in order to prove that China's changing attitude may be specific to the region and its conditions. China's strategic interests in Africa encourage Beijing to shape events on this continent. China's active diplomacy in Africa is mostly explained by the "energy" factor. However, China plays an active role in crisis regions in Africa rather than the Middle East, where it provides $62 \%$ of the energy imports. One of the three Peacekeeping Operations carried out by the UN in the Middle East has not provided staff to the United Nations Disengagement Observer Force (UNDOF) to date. China started to provide personnel support to The United Nations Interim Force in Lebanon-UNIFIL in Lebanon, after 2006, and attended with a team of 6 experts to the United Nations Truce Supervision Organization-UNTSO in Jerusalem.

One of the best examples of the Chinese active involvement to the conflict resolution and support to the UNPKO has been seen during the Darfur Crisis. China, which saw the Darfur Crisis as the internal problem of the Sudanese government, did not give consent to the deployment of any UN Peace Protection Operations in the region. However, due to this attitude, it faced the danger of boycotting the 2008 Beijing Olympics. Consequently, the Chinese administration met with Sudanese President 
Ömer al-Bashir, and he adopted the decision to authorize the UN-African Union joint power for intervention in 2007.

One of the most important consequences of the Darfur Crisis is that the Beijing administration has demonstrated that it can adapt its foreign policy principles in the strategic regions as required by its national interests. Likewise, the Sudan crises, that take place ten years apart, are important in terms of demonstrating that the Beijing administration is trying to strike a balance between national interests and sanctions directed to it by the international community.

In addition, the fact that it contributed to the solution of the crisis, and participated in UN Peacekeeping Operations shows that China's only strategic concern is not energy. As a matter of fact, China thinks that an instability that will spread from Darfur to neighbouring countries will endanger the agreements it has made with Sudan's neighbouring countries, Ethiopia, Libya, Chad and the Central African Republic.

A detailed and multidimensional analysis of Sino-African relations reveals that as China's investment and trade ties expand in remote regions, Beijing becomes more sensitive to instability in these regions, and when instability emerges from a regional scale, it can compromise the principle of not interfering with its internal affairs. As Beijing's global interests become widespread, security concerns increase simultaneously, and the crisis in which national interests are threatened has a more interventionist attitude. 


\section{Çin'in Afrika Kriz Bölgelerindeki Dış Politikasının Analizi: Darfur ve Güney Sudan Örnekleri}

Çin Halk Cumhuriyeti (Bundan sonra makalede Çin olarak kullanılacaktır) Devlet Başkanı Xi Jinping, 19. Çin Komünist Parti Kongresi'nde yaptı̆̆ı konuşmada, Çin'in politikalarında yeni bir çağ başladığını tüm dünyaya duyurmuştur. Mao’dan sonra Çin Komünist Partisi'nin başına geçen en güçlü lider görüntüsü çizen Xi, kendinden önceki Çinli liderlerin “ülkenin küresel güç hedefinin bulunmadığına” yönelik ifadelerinin aksine 2050’ye kadar ülkenin “dünya ulusları arasında gurur duyacağı bir yer edineceğini” ve "lider bir küresel güce dönüşeceğini”" ifade etmiştir. 1"

$\mathrm{Bu}$ öngörü Çin'in izleyeceği strateji ve politikaların nasıl şekilleneceği üzerine birçok tartışmayı da beraberinde getirmiştir. Bunun yanında Xi'nin doktrin olarak kabul edilebilecek "Yeni Çă̆ için Çin karakteristikleriyle sosyalizm" savı, Batı dünyası tarafından yeni bir ideolojik savaşın işareti olarak kabul edilmiştir. Dolayısıyla Çin, Mao döneminin dış politika argümanlarından en güçlüsüne dönüş mü yapacak sorusu güçlü bir şekilde gündeme gelmektedir. Bu soru, Batı dünyasında Uluslararası İlişkiler literatürüne iki şekilde yansımaktadır. Bunlardan ilki, Çin'in kendine özgü ve daha önceki büyük güçlerin gelişme evrelerine benzemeyen yükseliş sürecini tehdit olarak sunarken, diğeri Çin'in geleneksel dış politika çizgilerinden önemli tavizler vererek, uluslararası sistemin ilke ve işleyişine uyum göstermekte olduğunu öne sürmektedir. Bu bağlamda her iki yaklaşım da Pekin'in temel dış politika ilkesi olarak benimsediği "egemenliğe saygı, iç işlerine karışmama ve müdahale karşıtlığı” üzerinden geliştirilmektedir. Çin'in mevcut düzene tehdit oluşturduğu söylemi özellikle uluslararası kriz bölgelerinde uygulanması planlanan yaptırım ve müdahalelere karşı tutumu ile BM Barışı Koruma Operasyonları'na karşı politikaları gerekçe gösterilerek desteklenmektedir. Çin’in BM Barışı Koruma Operasyonları'na karşı sürdürmüş olduğu çekimser politika için ileri sürdüğü en önemli gerekçe; benimsediği ilkelerle doğru orantılı olarak tarafların rızasının sağlanması gerekliliğidir. BM Barışı Koruma Operasyonları'nın uygulanmasını ele alan Capstone Doktrini'ne $^{2 * *}$ göre de Barışı Koruma Operasyonları, "tarafların rızası”nın sağlanmasını operasyonların gerçekleşmesinin ön koşulu olarak kabul etmektedir. Fakat Capstone Doktrini, yerel unsurların rızasının sağlanamadığı durumlarda da Barışı Koruma Operasyonları kapsamında son çare olarak "güce başvurulabileceğini” öngörmektedir (UNPKO, 2008, s. 34). Capstone Doktrini tarafından kabul edilen ve bağımsız bir ülkede o ülkenin rızasının olmadığı durumlarda dahi güç kullanılabileceğini öngören bu ilke, Çin dış politikası tarafından kabul edilen “egemen devletlerin iç işlerine karışmama” ilkesi ile açık bir karşıtlık oluşturmaktadır. Ancak, bu karşıtlığa rağmen Pekin tarafından BM Barışı

1 "Konuşmanın tam metni için bknz: Xi Jinping, "SecureaDecisiveVictoryinBuildingaModeratelyProsperous SocietyinAllRespectsandStrivefortheGreatSuccessofSocialismwithChineseCharacteristicsforaNewEra", http://www.xinhuanet.com/english/download/Xi_Jinping\%27s_report_at_19th_CPC_National_Congress. pdf

$2{ }^{* *}$ Capstone Doktrini: BM Barışı Koruma Operasyonları’nın dayandığı temel ilke ve prensiplerin 2008 yılında yayınlanması sonucunda yazılı hale gelen ve operasyonlara meşruiyet sağlayan kurallar bütününü ifade eden Doktrindir. Meşruiyet, güvenilirlik ve yerel unsurların rızası olmak üzere üç temel kritere dayanmaktadır. Buna göre bir BM Barışı Koruma Operasyonu'nun başarılı olması, yerel unsurların rızasına ve krizin çözüm sürecinde sorumluluk üstlenmelerine bağlı olarak gerçekleşmektedir. (United Nations, United Nations Peacekeeping Operations Principles and Guidelines ("the Capstone Doctrine"), https:// www.un.org/ruleoflaw/blog/document/united-nations-peacekeeping-operations-principles-and-guidelinesthe-capstone-doctrine/, (e.t.21.01.2020). 
Koruma Operasyonları'na karşı izlenen geleneksel politikanın son yıllarda önemli ölçüde değişmeye başladığı görülmektedir. Bu kapsamda Çin’i operasyonlara en fazla finansal katkı sağlayan ikinci ülke konumuna getiren bu politikaların yeniden değerlendirilmesi, Çin dış politikasının ve bu politikaya ilişkin tehdit söylemlerinin değerlendirilmesi için önemli bir çerçeve sağlayacaktır.

BM'ye üye ülke olarak kabul edildiği 1971 tarihinden bugüne kadar Çin'in BM Barışı Koruma Operasyonları'na karşı tutumu, çekimserlikten askerî ve finansal destek vermeye doğru dönüşmüştür. Nitekim BM Barışı Koruma Operasyonları'na karşı değişen tutumu sonrasında Çin, 2012 yılında BM Barışı Koruma Operasyonları bütçesine $\% 3.9$ oranında katkı sağlarken bu oran 2018 yılı itibariyle \%10.3'e ulaşmıştır (Lanteigne, 2018, s.1). Bununla birlikte bugün Çin'in destek verdiği BM Barışı Koruma Operasyonları'nın çoğunlukla Afrika'daki kriz bölgeleri olması, Çin dış politikasındaki bölgesel stratejilerin ve diş politika vizyonunda meydana gelen değişimin BM Barışı Koruma Operasyonları aracılığıyla analiz edilebileceğini göstermektedir. Nitekim Pekin, Afrika'daki operasyonlara destek verirken Suriye Krizi'nde olası bir BM Barışı Koruma Operasyonu'na karşı çıkmaktadır. Bu aşamada Çin'in değişen tutumunun bölgeye ve şartlara özgü olabileceğini kanıtlaması açısından Afrika kriz bölgelerindeki operasyonlara verilen destek dikkat çekicidir. Çin'in Afrika'daki stratejik çıkarları Pekin'i bu kıtada olayları şekillendirme yönünde teşvik etmektedir. Bu açıdan düşünüldüğünde, Çin'in en fazla enerji ithal ettiği bölge olan Ortadoğu yerine Afrika'da aktif bir dış politika izlemesi, Afrika politikasının yalnız "enerji” faktörüyle açıklanmasının yetersizliğini göstermektedir. BM tarafindan Ortadoğu’ da yürütülen üç Barışı Koruma Operasyonu'ndan birisi olan BM Ayrılma Gözlemci Gücü (The United Nations Disengagement Observer Force- UNDOF)'a bugüne kadar personel sağlamayan Çin, Lübnan'da yürütülen BM Lübnan Geçici Görev Gücü (The United Nations Interim Force in Lebanon-UNIFIL)'e 2006'dan sonra personel desteği sağlamaya başlamış, Kudüs’te yürütülen (The United Nations Truce Supervision Organization-UNTSO)'ya ise yalnızca 6 kişilik uzman ekibi ile katılmıştır (UNPKO, 2019). Bu sebeple Çin'in diğer bölgelere oranla Afrika'daki kriz bölgelerinde aktif şekilde rol aldığı ve BM tarafından düzenlenen Barışı Koruma Operasyonları'na en fazla katkıyı sağladığı görülmektedir. Bu nedenle Çin’in Afrika politikasının geniş bir bakış açısıyla değerlendirilmesi gerekmektedir.

Çin'in Afrika ile ilişkilerinin başladığı 1950'li yıllardan bugüne kadar Çin hükümetinin temel dış politika söylemi anti-emperyalizm, ulusal bağımsızlıkların desteklenmesi, bağlantısızlık ve Güney-Güney iş birliği temaları üzerinden kurgulanmıştır. Çin’de yaşanan iç savaş sonrasında ortaya çıkan anti-emperyalist yeniden kalkınma süreci ile Afrika' da de-kolonizasyon sürecinin aynı tarihlerde yaşanmış olması Afrika ile ilişkilerin kurulmasında ortak duyguların oluşturulmasını kolaylaştırmıştır. Bütünsel bir bakış açısı ile incelendiğinde Çin dış politikasında Afrika, karşılıklı gelişmeyi teşvik eden ve güç ilişkilerinde ortak çıkara dayalı iş birliği geliştirme hedefinin yöneldiği temel bölgeyi oluşturmaktadır. Fakat Çin'in Afrika ülkeleriyle kurduğu ilişkilerin yapısal özellikleri (karşılıklı ticaretin sürekli Çin lehine fazla vermesi, inşaat ve enerji sektöründe yalnız Çinli işçilerin istihdam edilmesi ve Afrika'nın ucuz Çin malları için sürekli pazar konumunda olması) Batılı ve hatta bazı Afrikalı yöneticilerde Çin'in Afrika'da "yeni sömürgecilik" politikaları izlediği yönünde bir algı oluş(turul)masına yol açmıştır. 
Çin’in Afrika dış politikasına yönelik olarak geliştirilen "yeni sömürgecilik” iddiası, çoğunlukla Çin hükümetinin Afrika'daki enerji bağlantılarına ve karşılıklı ticaretin yapısına vurgu yapmaktadır. Nitekim Afrika'da doğrudan yabancı yatırım, dış ticaret hadleri ve Afrikalı nüfusun teknik konularda eğitilmesini içeren beşeri ilişkiler olmak üzere üç kanal üzerinden yürütülen Çin dış politikasının temel ilgi alanını enerji kaynakları oluşturmaktadır. Çin'in enerji ihtiyacı dış politikasını yönlendiren temel faktörlerden birisi haline gelmiştir. Çin dış politikasının temel amacının "enerjiyi sorunsuz ve kesintisiz elde etmek" olarak belirlenmesinin temel sebebi enerjinin ekonomik istikrarı için olmazsa olmazı olduğuna, ekonomik istikrarın da dolaylı yoldan rejimin devamlılığını sağlayacağına inanılmasıdır. Ekonomik istikrarı sürdürme zorunluluğu Çin'i giderek enerjiye bağımlı hale getirmekte ve bu sebeple enerji güvenliği; iktisadi güvenlik ve ulusal güvenlikle "bütünsellik" içerisinde değerlendirilmektedir. Bu açıdan bakıldığında enerji güvenliğinin Çin için giderek dış siyaset belirleyicilerinin başında geldiği görülmektedir (Karaca, 2012, s. 94).

Özellikle gelirinin \%98'inin (World Bank, 2017) petrol gelirlerinden oluştuğu ve petrol ihracatının neredeyse tamamının Çin'e gerçekleştirildiği Sudan gibi Afrika ülkelerinin Çin ekonomisi ve yatırımlarına olan bağımlılıkları, Çin-Afrika ilişkilerinde enerji faktörünü stratejik bir konuma yerleştirmektedir. Kıtada sayısı dört yüz milyonu bulan açlık sınırı altındaki nüfusun varlığı ve mevcut siyasi istikrarsızlıklar, Afrika hükümetlerinin Çin gibi yabancı yatırımcılara bağımlılıklarını pekiştirmektedir. $\mathrm{Bu}$ aşamada Afrika'yı enerji arz kaynaklarını çeşitlendirmek için firsat olarak gören Çin, bölgede yalnızca enerji ağları kurmakla kalmamış büyük alt yapı ve yol inşa projelerini üstlenerek bölge ülkelerine gelişim destekleri sağlamıştır. Nitekim Çin'in kıtadaki doğrudan yabancı yatırım miktarları, Afrika ülkelerinin tarihinde ilk kez \%5-\%7 aralığında ekonomik büyüme sağlamalarına ve Afrika'nın küresel ekonomi içerisinde Asya'dan sonra en hızlı büyüyen ikinci bölge olmasına olanak sağlamıştır (African Economic Outlook, 2016, s. 19).

Bu aşamada 2003 ve 2013 yıllarında yaşanan Darfur ve Güney Sudan krizleri Çin dış politikasında önemli bir dönüm noktasının yaşanmasına zemin hazırlamıştır. Darfur krizi sırasında uluslararası yaptırımlara katılmadığı için Pekin Olimpiyatları'nın protesto edilme tehlikesi ile karşı karşıya kalan Çin yönetimi geri adım atmış ve Güney Sudan krizi sonrasında BM Barışı Koruma Operasyonları'na askerî personel ile katkı sağlamıştır. Bu kapsamda Çin, kurulduğu tarihten bugüne kadar temel dış politika ilkesi olan ülkelerin iç işlerine karışmama, müdahale birliklerinde yer almama ve müdahale karşıtı duruş sergileme tutumunu ilk kez Afrika'da değiştirmeye başlamış ve BM operasyonları karşısında esnek bir politika izleyeceğinin işaretlerini vermiştir. Bununla birlikte Çin'in petrol ithalatında birinci sırada yer alan Ortadoğu bölgesinde krizlere müdahale konusunda geri planda dururken Afrika'da müdahaleci bir strateji izlemesi, Çin-Afrika ilişkilerinin yalnızca enerji arz güvenliği ile açıklanamayacağını göstermektedir. Çin-Afrika ilişkilerinin detaylı ve çok boyutlu bir analizi, Çin'in uzak bölgelerdeki yatırım ve ticaret bağları genişledikçe Pekin yönetiminin bu bölgelerdeki istikrarsılıklara daha duyarlı hale geldiğini, istikrarsızlıkların bölgesel boyutta yayılma tehlikesi ortaya çıktığında ise iç işlerine müdahale etmeme ilkesinden taviz verebileceğini ortaya çıkarmaktadır. 
Yukarıda değinilen temel konular üzerinden bu çalışmada; Çin'in Sahraaltı Afrika'da sürdürdüğü dış politika ve BM Barış1 Koruma Operasyonları'na karşı gösterdiği tutum değişikliği, Darfur ve Güney Sudan krizleri üzerinden analiz edilmiştir. Çalışmanın ilk bölümünde Çin dış politikasında belirleyici olan temel ilkeler ile bu ilkelerde meydana gelen değişimin Çin'in Afrika politikası üzerindeki etkisi incelenmiştir. Bu kapsamda Çin ile Afrika ülkeleri arasındaki ilişkiler 1950-1971, 1971-1989, 1989-2005 ve 2005 sonrası olmak üzere dört farklı döneme ayrılarak ele alınmıştır. İlişkilerin dönemlere ayrılmasında Çin iç politikasında ve uluslararası sistemde yaşanan gelişmelerin etkisi ile Çin-Afrika ilişkilerinde yaşanan kırılma noktaları temel alınmıştır. İlk dönem olan 19501971 yılları, Çin'in iç siyasetinde komünist rejimi pekiştirme dönemi iken dış ilişkilerinde ideoloji temelli politikalar geliştirdiği, komünist hareketlere ve bağımsızlık savaşlarına destek verdiği bir dönemdir. 1966'da Mao tarafından başlatılan ve büyük yıkımlara yol açan Kültür Devrimi'nin etkisiyle 1989'a kadar kendisini uluslararası sistemden izole eden Çin, bu dönemde dış politikadan ziyade iç politik konular ve ekonomik kalkınması üzerinde durmuştur. Üçüncü dönemin başlangıcı olarak alınan 1989 yılı, Tiananmen Olayları sonrası uluslararası yaptırıma ve dışlanmaya maruz kalan Çin için Afrika'nın uluslararası desteğin ve iş birliğinin sağlanabileceği alternatif bir bölge olarak yeniden keşfedildiği yıl olmuştur. 2000'li yıllardan itibaren Çin-Afrika ilişkileri stratejik ortaklık boyutuna varmıştır.,. Bu dönem Çin için bölgesel örgütlerde aktif şekilde rol alınan ve bölgesel krizlerde arabulucu rolü üstlenilmeye başlanan dönem olmuştur.

Çalışmanın ikinci kısmında Çin ile Afrika arasındaki ilişkilerin stratejik ortaklık boyutuna taşınmasına yol açan ve karşılıklı bağımlılığı artıran dış ticaret ve enerji güvenliği gibi faktörler analiz edilmiştir. Çin ile Afrika ülkeleri arasındaki karşılıklı ticaretin yapısı sürekli Çin lehine fazla veren bir özellik göstermekte bu da Afrika ülkelerinin Çin'e karşı tutumuna olumsuz şekilde yansımaktadır. Diğer yandan Çin'in Afrika'daki petrol arama, çıkarma ve işletme sektörlerine yaptığı yatırımlar ile bölgeden yaptığı enerji ithalatı Çin'in Afrika'ya karşı daha hassas ve aktif bir dış politika geliştirmesini zorunlu hale getirmektedir. Bu da dolaylı olarak Çin'in bölgedeki istikrarın sağlanması için kriz bölgelerine müdahale etme ve BM Barışı Koruma Operasyonları'nın bölgedeki faaliyetlerine destek verme politikası izlemesine yol açmaktadır. Bununla birlikte Afrika'dan gerçekleştirilen petrol ithalatında yalnızca \%2 düzeyinde bir paya sahip olan Sudan'da Pekin'in barış operasyonlarına ve arabuluculuk çabalarına aktif şekilde destek vermesi Çin'in tek kaygısının enerji arzı olmadığına işaret etmektedir.

Çalışmanın son kısmında Çin’in BM Barışı Koruma Operasyonları'na karşı politikası ve bu politikada son y1llarda meydana gelen değişim, Darfur ve Güney Sudan krizleri üzerinden yorumlanmaya çalışılmıştır. Çalışma, 2003 yılında yaşanan Darfur krizinde Hartum hükümetini destekleyen ve uluslararası yaptırımlara karşı çıkan Çin hükümetinin Güney Sudan krizinde, Hartum'a karşı Juba’yı yani Güney Sudan ayrılıkçı hareketini desteklediğini ortaya koymuştur. On yıl ara ile gerçekleşen bu iki kriz, Pekin yönetiminin ulusal çıkarları ile uluslararası toplum tarafından kendisine yönelen yaptırımlar arasında bir denge kurmaya çalıştığını gösteren örnek olaylar konumundadır.

Çin, Sudan hükümeti ile Güney Sudan'ın bağımsızlığını isteyen ayrılıkçı güçler arasındaki çatışmalarda petrol kaynaklarının yoğun olduğu Güney Sudan'da hükümeti tanıyan ilk ülkelerden birisi olmuş ve krizin çözülmesi sürecinde arabulucu rolünü 
üstlenerek uluslararası örgütlerle ortak hareket etmiştir. Sudan'da on yıl içerisinde yaşanan iki krizde Çin, BM Barışı Koruma Operasyonları'na askerî personel ile destek vererek temel dış politika ilkesi olan iç işlerine müdahale etmeme politikasından belirli ölçülerde taviz verebileceğini göstermiş, bölgesel ve küresel güçler nezdinde güvenilirliğini artırmıştır.

Çalışmada izlenen temel yöntem Çin'in dış politika ilkeleri, Afrika'da izlediği açılım politikasının evreleri ve BM Barışı Koruma Operasyonları'na karşı tutumuna ilişkin birincil kaynakların karşılaştırmalı şekilde analiz edilmesine dayanmaktadır. BM Barışı Koruma Operasyonları'na ilişkin veriler doğrudan BM istatistiklerinden ve Çin Ulusal Savunma Bakanlığı raporlarından elde edilmiştir. Yapılan kaynak taraması sonuçları, Çin'in Afrika politikasına ilişkin çok sayıda akademik çalışma ve siyasi rapor olduğunu göstermekte ancak Çin'in BM Barışı Koruma Operasyonları'ndaki değişen tutumuna ilişkin sınırlı sayıda çalışma olduğuna işaret etmektedir.

Çin'in BM Barışı Koruma Operasyonları'na ilişkin politikalarını ele alan çalışmalar, özellikle 2000 yılından sonra hız kazanmaya başlamıştır. Bu konuda yapılan ilk çalışmalardan bir tanesi He Yin tarafından 2007 yılında yayınlanmıştır. "China’s Changing Policy on UN Peacekeeping Operations” başlığını taşıyan çalışmada He, Çin’in BM Barışı Koruma Operasyonları'na karşı politikalarında değişimin başlangıcı olarak 1999 yılını kabul etmekte ve bu değişimi motive eden hızlandırıcı sebepler ile bu politikanın daha aktif olmasını yavaşlatan engelleri incelemektedir (He, 2007, s. 9-12). 2018 yılında "China Rising and Its Changing Policy on UN Peacekeeping” başlıklı ikinci çalışmasını yayınlayan He, Çin'in BM Barışı Koruma Operasyonları'na daha aktif katılımını sağlayan en belirleyici unsurun Çin'in ulusal kimliği olduğunu iddia etmiştir (He, 2018, s.254).

Bu konuda yapılan çalışmalardan bir diğeri “China's Shifting Attitude towards United Nations Peacekeeping Operations" başlığı ile yayınlanmıştır. Yazar bu çalışmada Çin'in BM Barışı Koruma Operasyonları'na yönelik tutum değişikliğinin 1990'lardan sonra meydana gelmeye başladığını öne sürmüştür. Buna göre bu değişim, BM'nin 2000 yılında yayınladığı Brahmi Raporu ile BM misyonlarını yeniden tanımlaması ve Çin'in misyonlara yönelik sahip olduğu geleneksel algının değişmeye başlaması sonucunda etkileşimsel bir süreç içerisinde ortaya çıkmıştır (Stähle, 2008, s.631). Çin’in BM Barış1 Koruma Operasyonları'na yönelik değişen tutumunu benzer bir bakış açısı ile ele alan bir başka çalışma 2011 yılında Masuda tarafından yayınlanmıştır. "China’s Peacekeeping Diplomacy and Troop Dispatch: A New Avenue for Engagement with the International Community", başlıklı çalışmasında Masuda, uluslararası güvenliğin sağlanmasında Çin'in daha yapıcı bir rol üstlenmesini sağlamak üzere BM misyonlarına askerî birliklerini göndermeye başlaması ile BM'nin uluslararası sistemdeki otorite ve rolüne de katkı sağladığını ifade etmiştir (Masuda, 2011, s.3).

Çin'in BM misyonlarına katılımını Çin'in iç dinamikleri açısından ele alan çalışmalar, Çin'in BM misyonlarına yönelik tutum değişikliğini uluslararası sistemde saygınlık kazanma, enerji ve ekonomi iş birliklerine katkı sağlama gibi unsurlar üzerinden açıklamaktadırlar. Bu çalışmalardan bir tanesi, Çin'in Sudan, Liberya ve Kongo'da BM misyonlarına katılımının Çin'in sorumlu bir güç olduğunu gösterdiğine işaret etmektedirler (Ayenagbo vd., 2012, s.22). Bir başka çalışma ise Çin'in BM Barışı Koruma Operasyonları'na aktif katılımına yol açan politika değişiminin, Çin’i dış dünya ile daha fazla bütünleştirmeyi hedefleyen dış politikanın bir bileşeni olarak çıktığını öne 
sürmektedir (Matsuda, 2016, s. 50-51). Bir başka çalışma ise 2000'li yıllardan itibaren Çin'in BM Barışı Koruma Operasyonları'na yönelik değien tutumunun arkasında yatan temel sebepleri ortaya koymaya çalışmıştır. Buna göre Çin'in BM Barışı Koruma Operasyonlarına giderek daha fazla katılım sağlamasının sebebi bu ülkelerden sağlanan kaynak ithalatından ziyade bu ülkelerin Çin ürünleri için taşıdığı pazar olanakları şeklinde sunulmuştur (Cho, 2018, s.1).

Çin'in BM Barışı Koruma Operasyonları'na yönelik politikalarını eleştirel açıdan ele alan bir çalışma 2018 yılında yayınlanmıştır. Lanteigne tarafından yayınlanan çalışmada Çin'in uluslararası sistemdeki yükselen konumuna rağmen BM Barışı Koruma Operasyonları'na hâlâ orta büyüklükte bir güç oranında destek verdiği ifade edilmektedir. $\mathrm{Bu}$ sebeple yazara göre Çin, devlet egemenliğine vurgu yapan geleneksel görüşü ile modern barışı koruma yaklaşımının nasıl uzlaştırılacağı üzerinde daha fazla düşünmeli ve sorumlu büyük güç olabilmenin gereklerini yerine getirmelidir (Lantaigne, 2018, s.1).

Buradan hareketle Çin'in BM Barışı Koruma Operasyonları'na yönelik politikalarını ele alan çalışmaların bu politikaları tarihsel şekilde ele alarak 2000'li yıllardan sonra ortaya çıkan tutum değişimine odaklandığı görülmektedir. Bu değişimi açıklamaya çalışan makalelerin bir kısmı Çin'in iç dinamiklerine ve yönetici elitin bu konuda değişen algısına atıf yaparken bir kısım çalışmalar uluslararası sistemde ortaya çıkan beklentilere ve BM'nin kendi iç dinamikleri ve Barışı Koruma Operasyonları'nın değişsen misyonlarına atıf yapmaktadir.

Bu noktada bu çalışma, Çin'in BM Barışı Koruma Operasyonları'na yönelik tutum değişikliğini bölgesel farklılıklar açısından ele alan ve bu misyonlara yönelik politikaların her bölgede farklı motivasyonlar ile değişiklik gösterebildiğini ortaya koyması açısından literatüre önemli bir katkı sağlamayı hedeflemektedir. Bu aşamada Çin’in Barışı Koruma Operasyonları'ndaki değişen tutumunun Çin dış politikasında genel bir dönüşümün işareti olup olmadığı veya bu tutum değişikliğinin uluslararası sisteme ne gibi yansımaları olacağı ise araştırılmaya ihtiyaç duyulan konular olmayı sürdürmektedir.

\section{Çin Dış Politikası’nda Afrika ve Karşılıklı İlişkilerin Gelişimi}

Bir ülkenin uluslararası sistem içerisinde sahip olduğu konum ve etkisinin kapasitesi, o ülkenin uygulamakta olduğu dış politikanın bir yansıması olarak ortaya çıkmaktadır. Bu sebeple ülkelerin belirlemiş oldukları gelecek vizyonu, uygulanacak dış politikanın bu vizyon doğrultusunda uyarlanmasını gerektirmektedir. Her ne kadar ülkelerin dış politika eğilimlerini belirleyen stratejik düşüncelerin "yapışkan” olduğu ve değişmelerinin kolay olmadığı kabul edilmiş olsa da (Gilboy ve Heginbotham, 2012, s.42) bir ülkenin diş politikasında iç siyasetin ve uluslararası şartların gerektirdiği değişimlerin yapılması zorunlu hale gelmektedir. Bu sebeple bir ülkenin dış politika ilkelerinin anlaşılması, o ülkenin dış politikası üzerinde süreklilik ve değişim unsurları analizi yapılmasını gerektirmektedir. Dış politikada gözlenen sürekliliğin kazandıracağ istikrar ile değişimin getireceği belirsizlik arasında bir "çekişme” ortaya çıkacağı savunulmuş olsa da (Sümer, 2010, s.73) ortaya çıkacak bu çekişmenin ülkelerin dış politikalarında dinamik bir yapı oluşturacağ 1 yadsınmamalıdır. Özellikle Çin gibi uzun bir geçmişe ve imparatorluk kökenine sahip olan bir ülkenin dış politikasında benimsediği sürekliliklerin ve aynı zamanda yüksek nüfus, yoksulluk ve artan enerji tüketiminin yarattığı ekonomik büyüme 
baskısının zorunlu kıldığı değişimin ciddi bir çekişmeye yol açması kaçınılmazdır. Nitekim uluslararası literatürde Çin dış politikasının 1990'lı yıllardan sonra teorik ve pratik boyutlarda geçirmiş olduğu değişim ve dönüşümün anlaşılması, dış politika analizi üzerine yoğunlaşan bilim insanlarının temel sorunsalı haline gelmiştir.

Çin'in ideolojik bir iç savaş sonucunda Soğuk Savaş rekabeti içerisindeki uluslararası sisteme katılmış olması, resmi dış politikanın ideolojik kaygılar etrafında şekillenmesini zorunlu kılmıştır. Soğuk Savaş’ın rekabete dayalı güç ilişkileri ile Çin’in ülke içindeki ekonomik, sosyal ve siyasi çıkmazları Pekin'deki yöneticilerin dış politikayı keskin hatlar çerçevesi içerisinde durağan bir pozisyonda tutmalarına yol açmıştır. Bu kapsamda iç politikada istikrarı sağlamaya çalışan Çinli politikacılar, dış politikalarını 1955 Bandung Konferansı'nda resmileşen ve içerisinde karşılıklı saygı, iç işlerine müdahale etmeme, toprak bütünlügüün̈n korunması gibi ilkeleri de barındıran beş temel ilke etrafında yürütmüşlerdir. Kuruluş döneminde Çin dış politikasının iç işlerine müdahale etmeme ilkesinin en önemli istisnası üçüncü dünya ülkelerindeki anti-emperyalist ulusal bağımsızlık hareketlerine verilen destek olmuştur. Bu anlamda Çin'in kurulduğu ve ideolojik kaygıların yoğun olduğu yılların Afrika'da ulusal bağımsızlık hareketlerinin doğuşuna rastlamış olması, o dönem için Çin-Afrika ilişkilerinin yapısını belirleyen en önemli unsur olmuştur (Alden ve Alves, 2008, s.47).

Çin-Afrika ilişkilerinin başladığı 1950'li yıllardan bugüne kadar Afrika, Çin dış politikasında meydana gelen ideolojik, diplomatik ve ekonomik eğilimlerin öncelikli uygulama alanı bulduğu bir kıta olma özelliği taşımaktadır. Çin’in iç politika ihtiyaçlarına göre şekillenen dış politikası zaman içerisinde dönüşüme uğradıkça Çin-Afrika ilişkileri de bu dönüşümün yansımalarından etkilenmiştir. Çin-Afrika ilişkilerinin tarihsel bir analizi yapıldığında; 1950-1971 yıllarının ideolojik temelli ilişkilerin kurulduğu, 19711989 döneminin Çin'in ABD ve SSCB ile olan ilişkilerine odaklanması sebebiyle Afrika'nın ihmal edildiği, 1989-2005 döneminin Tiananmen Olayları sonrasında uluslararası sistemde yalnız bırakılan Çin hükümetinin, Afrika'ya yeniden yöneldiği ve 2005 'den günümüze kadar geçen sürenin Afrika'da Çin'i güvenilir bir güç haline getirdiği dönemler olduğu görülmektedir.

Tüm bu dönemler içerisinde Çin dış politikasındaki en önemli dönüşüm, yüksek ekonomik büyümenin hem sebebi hem de sonucu olarak ortaya çıkan enerji ihtiyacının sorunsuz şekilde karşılanması alanında yaşanmıştır. Enerji güvenliği; diğer ülkeler için olduğu gibi Çin için de "enerji kaynaklarına yeterli erişim ve enerjiyi sorunsuz elde etme" anlamına gelmektedir. Ancak bunların yanında Çin için enerji güvenliğinin sağlanması, sürdürülebilir ekonomik büyüme, güçlendirilmiş ordu, Tayvan politikasının tavizsiz biçimde yürütülmesi ve dolayısıyla Komünist Parti iktidarının devamlılığı anlamına gelmektedir (Karaca, 2012, s.99). Çin'in son çeyrek yüzyılda gösterdiği yüksek ekonomik büyüme ve gelişme, bu ülkenin sahip olduğu gücü gelecekte sistem ile bütünleşme yönünde mi yoksa sisteme karşı mücadele etme yönünde mi kullanacağına ilişkin tartışmaların başlamasına yol açmıştır (Karaca, 2011, s.91).

$\mathrm{Bu}$ tartışmaların önemli bir kısmını, Çin'in Afrika ve diğer az gelişmiş bölgelerde uyguladığı dış politika anlayışı oluşturmuştur. Söz konusu dış politika anlayışı Çin'in Batılı güçler tarafından insan hakları ihlallerine, teröre ve savaş suçlarına destek vermekle suçlanmasına yol açmaktadır. Bu konuda Çin için enerji elde ettiği kaynak 
ülkelerdeki istikrarsızlık, doğrudan bir enerji güvenliği sorunu olarak görülmektedir. Çin bu ülkelerdeki istikrarsızlığın farklı aktörler tarafından yaratıldığını düşünmektedir. Bu ülkelere yönelik müdahaleci anlayışı bu ülkelerin iç işlerine karışma ve bağımsızlıklarına tehdit olarak görmektedir (Karaca, 2012, s.108). Bu anlayış kendisini Afrika'da diğer kıtalara oranla daha fazla ön plana çıkarmıştır. Bu kapsamda Afrika'da izlenen Çin dış politikasının seyri, Pekin tarafından kabul edilen temel güvenlik, çıkar ve tehdit algılamalarını da doğrudan yansıtmaktadır. Bu sebeple Çin dış politikasının bugünkü Afrika politikasının anlaşılması, 1950-1971 yıllarını içeren erken dönem ilişkilerinin öncelikle analiz edilmesini gerektirmektedir.

\section{Afrika'da İdeoloji Temelli İlk Bağlantılar: 1950-1971}

Çin-Afrika ilişkilerinin bugünkü yapısının anlaşılması için 1950-1970 döneminde oluşturulan bağların iyi analiz edilmesi gerekmektedir. Nitekim Çin'in bugün Afrika'daki varlığı Mao döneminde kurulan ilişkiler üzerinden sürdürülmektedir. 1950'li yılların başlarında Çin'in Afrika ülkeleri ile ilişkilerine özel bir önem vermesinin başlıca sebebi, içerdeki ideolojik gündemin yanı sıra dışarda Çin'e karşı yürütülen izolasyon politikasının kaldırılmasına yönelik çabaların etkisidir. Bu dönemde Çin'in Afrika politikası üç temel değişmez unsur etrafında şekillenmiştir: “Çin modeli”nin ihracı, süper güçlere karşı mücadele ve Çin'in üçüncü dünya politikası (Alden ve Alves, 2008, s.47). Bu kapsamda 1950'li yıllardan başlayarak Afrika, Çin’in sömürgecilik karşıtı ideolojik dış politika faaliyetlerinin merkezi konumuna gelmiştir (Hanauer vd., 2014, s.19).

Gerçekten Çin'in kuruluş sonrası ilk yıllarında rejimin devam edebilmesi için gerekli uluslararası tanınmanın sağlanması, bağımsızlığını henüz kazanmakta olan Afrika ülkeleri üzerinden gerçekleştirilmek istenmiş ve bu sebeplerle Pekin, Mao Dönemi'nde (1949-1976) ekonomik ve askerî yardımlarla Afrika'da varlık göstermiştir (Zhao, 2014, s.1035). Bu kapsamda ilk olarak Kore Savaşı'ndan sonra Afrika'ya açılan Çin, 1955 Bandung Konferansı'ndan sonra daha aktif bir politika izlemeye başlamıştır. Bandung Konferansı'nda dönemin Dışişleri Bakanı Zhou Enlai birçok Afrika lideri ile bir araya gelmiştir. $\mathrm{Bu}$ görüşmeler sonucunda Çin ile ilk diplomatik ilişkileri kuran Afrika ülkesi Mısır olmuş ve Kahire uzun yıllar Çin'in Afrika'daki politikaları için temel üs rolü oynamıştır. Afrika ile kurulan bu ilk dönem ilişkiler Bandung ruhunun da etkisiyle "Üçüncü Dünya'da birlik" söylemi üzerinden sürdürülmüştür. İlk dönem kurulan bu diplomatik bağların etkisiyle Fas ve Cezayir 1958'de, Sudan ve Gine 1959'da Çin'i resmi olarak tanımıştır (Alden ve Alves, 2008, s.47).

$\mathrm{Bu}$ dönemde Çin'in Afrika'ya müdahil olması oldukça sınırlı kalmış ve var olan müdahaleler de Sovyetler Birliği ile ittifak kapsamında şekillenmiştir. Buna rağmen 1957'de kurulan Afrika-Asya Halkları Dayanışma Örgütü (AfroAsian People’s Solidarity Organization) Çin'in Afrika' daki müdahaleleri için temel aracı rolü üstlenmiştir. 1960'larda Çin-Sovyet ayrılığından sonra değişim göstermeye başlayan Çin'in Afrika politikası, Afrika'nın hem ABD hem de SSCB'ye karşı ideolojik mücadelenin verilebileceği bir bölge olarak görülmesine yol açmış ve bu doğrultuda bölgedeki ulusal bağımsızlık hareketleri desteklenmiştir (Alden ve Alves, 2008, s.48). 1960 yılında Çin-Afrika Halklarının Dostluğu Birliği (China-African People’s Friendship Association) kurulmuş, Zhou Enlai 1963 Aralık’tan 1964 yılının Şubat ayına kadar toplam yedi hafta süren uzun bir Afrika 
turu düzenlemiştir. Bu turda toplam on ülkeyi ziyaret eden Çin Dişişleri Bakanı, Çin'in özgürlük hareketlerine verdiği desteği öne çıkartan girişimlerde bulunmuştur.

$\mathrm{Bu}$ dönemde Mozambik’te Mozambik Kurtuluş Cephesi (Mozambique Liberaiton Front-FRELIMO), Angola'da Angola Kurtuluş Cephesi (Movimento Popular de Libertaçao de Angola-MPLA ve National Liberation Front of Angola-FLNA), Cezayir'de Ulusal Kurtuluş Cephesi (Front de Libération Nationale-FLN) ve Kongo-Kishasa'daki "isyancılar" ile Afrika ilişkilerini etkileyecek ilişkiler kuran Çin, özellikle Kongo, Angola, Mozambik, Gana, Nijer ve Brundi'deki bağımsızlık mücadelelerine önemli ölçüde destek vermiştir. 1964'de Nijer Cumhuriyeti'nde Fransız hükümeti yanlıları ile savaşmak için Gana'da gizli bir gerilla eğitim kampı kurulmasında Nkrumah'a destek vermiş aynı zamanda Burundi merkezli Gaston Soumialot'un grubuna olduğu kadar Pierre Mulele önderliğindeki Kongolu isyancılara da asker ve eğitim desteği sağlanmıştır. Bazı kaynaklara göre 1967-1976 arasında 15 Afrika ülkesine en az 142 milyon dolarlık silah gönderilmiştir. Çin'in isyancı gruplara verdiği bu destekler pek çok Afrika liderinin, Çin’i güvenilmez görmesine yol açmıştır. (Alden ve Alves, 2008, s.49-50).

1966'da Kültür Devrimi başlayınca Çin'in kıtadaki radikal faaliyetleri uzun süreli olmamış ve Çin iç politikaya dönmüştür. Çin, iç politik sorunların yanında bu dönemde dış politikada da büyük değişimlerle karşı karşıya kalmıştır. Sovyetler Birliği’nin revizyonist politikalarının, ABD’nin emperyalist politikaları kadar tehlikeli görüldüğü bu dönem, her iki kutup lideriyle ilişsilerde değişimi kaçınılmaz kılmıştır. Bu dönem iç ve dış politikada yaşanan değişimin sancıları Çin'in üçüncü ülkelere olan politik ilgisinde azalmaya yol açmıştır. Bu kapsamda Çin'in Afrika'ya yönelik erken dönem politikası 1971 sonrasında değişmeye başlamıştır.

\section{Afrika'da İhmal Yılları: 1971-1989}

Kültür Devrimi'nin etkisini kaybetmesi ve 1978'de reform yanlısı Deng Xiaoping'in parti yönetimine gelmesi ile Çin'in iç ve diş politikada öncelikleri değişmiştir. Bu yıllarda piyasa eğilimli ekonomik reformlar uygulayan Çin yönetimi, uluslararası sistemde yaşanan yumuşamanın da etkisiyle gelişmiş Batılı ülkelere yönelik yakınlaşma politikası izlemeye başlamıştır (Zhao, 2014, s.1035). Bu politikaların bir sonucu olarak ortaya çıkan hızlı değişim süreci içinde Çin, bütüncül bir üçüncü dünya politikası sergileyememiş ve 1980’li yıllar Afrika'nın “ihmal yılları” olarak değerlendirilmiştir. Çin’in yüzünü tekrar üçüncü dünyaya dönmesi için Soğuk Savaş’ın bitişine eşlik eden Tiananmen Olayları'nı beklemek gerekmiştir (Üngör, 2009, s.33).

Tiananmen Olayları sonrasında Batılı ülkeler ekonomik yaptırımlar uygulayarak Çin’in uluslararası sistemde yalnız bırakılmasını sağlamaya çalışmışlardır. Batılı ülkelerin bu politikaları karşısında Afrika ülkeleri Çin'e yönelik politikalarını üç temel kaygı ile şekillendirmişlerdir. Bunlardan ilki, kendilerini Batılı ülkeler tarafindan dayatılan "demokratikleşme projelerinin" tehdidi altında hisseden Afrikalı elitlerin iktidar kaygılarıdır. Bu kapsamda Afrikalı yönetici-elitler öz-çıkarları gereği Batı karşısında bir denge unsuru oluşturmak adına Çin yönetimine siyasi destek sağlayan bir dış politika belirlemişlerdir. İkincisi, Batılı "neo-emperyalist müdahale" tutumu karşısında duyulan bağımsızlı̆̆ını kaybetme endişesi olmuş ve bunun bir sonucu olarak Afrika'da gelişen şiddetli tepki Afrikalı yöneticilerin Çin'e yaklaşması sürecini hızlandırmıştır. Sonuncusu ise Batı'dan aleni şekilde eleştiriye tâbi tutulan Pekin'e karşı Üçüncü Dünya dayanışması 
kapsamında geliştirilen pragmatik anlayıştır (Taylor, 1998, s.447). Dolayısıyla 1971-89 dönemi boyunca Batının Çin'i yalnızlaştıran yaklaşımları ile Afrika'ya yönelik neoemperyalist yaklaşımları bölge ile Çin' in ilişkilerinin yeniden gelişmesinin önünü açmıştır.

\section{Çin Dış Politikasıı'nda Afrika'nın Yeniden Keşfi: 1989-2005}

1971-1989 döneminde Çin yönetimi ile Batı arasında gelişen ilişkiler 1989 Tiananmen Olayları sonrasında kesintiye uğramış ve Çin küresel sistemde ciddi yaptırımlarla karşılaşmıştır. Çinli yöneticilerin şiddet kullanarak bastırdığı Tiananmen Olayları sonrasında Batıyla ilişkilerin olumsuz gidişatı, Çin’i uluslararası arenada alternatif müttefik arayışlarına itmiş ve bu tarihten sonra Asya, Afrika ve Latin Amerika ülkelerinin Çin dış politikasındaki önemi giderek artmıştır (Üngör, 2009, s.33). 1992 yılında Çin Dışişleri Bakanı Qian Qichan Afrika'da 14 ülkeden fazla ülkeyi ziyaret etmiş, Afrikalı diplomat ve elçilerle yüzden fazla üst-düzey toplantı gerçekleştirmiştir (Tull, 2006, s.462). Bu dönemlerde sürekli hale gelen ekonomik büyümesi nedeniyle kaynak sıkıntısı ortaya çıkınca Çin, Afrika’yı kaynak merkezi ve ürünleri için pazar olarak belirlemiştir (Zhao, 2014, s.1035). Afrika'nın doğal kaynak arzı sağlayabilecek bir bölge olarak kabul edilmesi sonrasında Pekin tarafından Afrika'ya dev yatırım hamlesi başlatılmıştır (FeiLing ve Elliot, 2014, s.1013).

Dönemin Çin Komünist Partisi Genel Sekreteri olan Jiang Zemin'in 1996 yılında Kenya, Etiyopya, Mısır, Mali, Namibya ve Zimbabve'yi içine alan Afrika gezisinde Çin medyası, yoğun şekilde Afrika'nın Çin dış politikası için taşıdığı önemi vurgulamış, Afrika'yı yabancılaştıran Avrupa ve Birleşik Devletlerin aksine bu kıta ile güçlü bağlar geliştireceklerini duyurmuşlardır (Payne ve Veney, 1998, s.867). Bu vizyonun açıklanması sonrası geliştirilen ilişkiler sonrasında karşılıklı ticaret ve yatırım kanalları teşvik edilmiş, 1980’de yalnızca 1 milyar dolar civarında olan Çin-Afrika ticareti 1996 yılında 4.03 milyar dolara, 2000 yılında 10.5 milyar dolara ve 2005 yılında 40 milyar dolara ulaşmıştır (Ighobor, 2013). Bu dönemde ayrıca Çin'in yabancı ülkelere yaptığg dış yardımların yöneldiği temel kıta Afrika olmuştur. 1990 yılında Çin'in dış yardımda bulunduğu 52 ülkenin 24'ünü Afrika ülkesi oluştururken, 1993 yılında Çin hükümeti tarafında yapılan dış yardımlar arasında Afrika ülkelerinin oranı \%56'ya ulaşmıştır (Taylor, 1998, s.450).

Afrika'dan Çin'e doğal kaynak ithalatı ve Çin'den Afrika'ya mamul ürün ihracatı artışı Çin ilgisinin diğer bir göstergesidir. Çin'in Afrika açılımının başarısı, kıtada sert rekabetlerin de önünü açmıştır. Çin bu sert rekabeti kendi lehine çevirebilmek amacıyla üye olduğu bölgesel ve uluslararası kuruluşları politikalarının bir aracı olarak kullanmaya başlamıştır. Bu kapsamda Çin'in 2000'li yıllardaki Afrika politikasının içişlerine müdahale etmeme ve çok kutupluluğa dayandığı görülmektedir (Doğan, 2017, s. 154). Pekin yönetiminin Afrika dış politikasının aracı olarak kullandığı ve çok kutupluluğu teşvik etmeye yönelen unsurlarından bir tanesi Çin-Afrika İş Birliği Forumu (Forum on China-Africa Cooperation-FOCAC)'ın kurulmuş olmasıdır. Çin-Afrika arasındaki diplomatik ilişkilerin kurumsallaştırılmasına yönelik atılmış en önemli adımlardan bir tanesi olan FOCAC kapsamında her üç yılda bir bakanlık düzeyinde zirve toplantıları yapılmaktadır. $\mathrm{Bu}$ kurumlar aracılığıyle Afrika'da güvenilirliğini artıran Çin, şuanda 54 Afrika ülkesinin tamamı tarafından tanınmış durumdadır ve 31 Afrika ülkesinde diplomatik misyona - büyükelçiliğe sahiptir (FOCAC, 2018). 


\section{Afrika-Çin İlişkilerinde Bölgesel ve Uluslararası Örgütlerin İşlevi: 2005 ve Sonrası}

21. yüzyılın ilk on yılında Çin sürdürdüğü politik ve ekonomik girişimlerle, ASEAN ve Şangay İş Birliği Örgütü (ŞİÖ) üye ülkeleri ile Latin Amerika ve Karayip ülkeleri arasındaki ilişkileri kurumsallaştırmış, 2006 Kasım ayında bu ilişkiler ağına Afrika ile stratejik iş birliğini de eklemeyi başarmıştır. (Campbell, 2005, s.148). Çin'in Afrika' daki bu yeni politikası enerji kaynakları, yeni pazar ve yatırım olanakları, gelişmeye dair iş birliği ve stratejik ortaklığın oluşturulmasından oluşan dört temel faktör tarafindan belirlenmiştir (Alden, 2005, s.148). Bu faktörler çerçevesinde atılan en önemli adımlardan bazıları 2005 yılında Çin-Afrika Ticaret Odası'nın (Chinese-African Chamber of Trade) açılması ve 2007 y1lında Çin-Afrika Gelişim Fonunun (China-Africa Development Fund) kurulması olmuştur. Bu gelişmeler kapsamında Çin yönetimi tarafından ilki 2006 yılında ikincisi ise 2015 yılında olmak üzere "Çin'in Afrika Politikası" başlıklı resmi politika belgeleri kamuoyu ile paylaşılmıştır (Cheng vd., 2018, s.599). 2006 yılında yayınlanan ilk politika belgesinde Çin'in Afrika kıtası ile ilişkilerinde bölgesel örgütler ile iş birliğine öncelik verileceği, bölgesel sorunların çözümünde Afrika Birliği'nin öncü rolünün destekleneceği vurgulanmıştır. Yine bu belgede Çin yönetimi, BM tarafindan bölgedeki krizlerin çözümüne yönelik olarak yürütülen Barışı Koruma Operasyonları'na desteğini sürdüreceğini fakat burada öncelikli şartın Afrika ülkelerinin egemenliğinin korunması olduğunu açıkça dile getirmiştir. $^{3 * *} 2015$ yılında yayınlanan ikinci Afrika Politika Belgesi ise 2000 yılında kurulan Çin-Afrika İşbirliği Forumu'nun 15. Yılı olması sebebiyle bu örgütün Çin-Afrika ilişkilerinin gelişimine sağladığı katkıya vurgu yapmıştır. Aynı zamanda Afrika Birliği tarafindan kabul edilen 2063 Vizyonu'nun Çin tarafından desteklendiğini belirten belge, Çin Rüyası (China Dream) ve Afrika Rüyası (African Dream) hedeflerinin halklara daha müreffeh ve mutlu bir yaşam sağlamayı hızlandırdığını kabul etmiştir. ${ }^{4^{* * * *}}$

Çin ve Afrika ülkeleri arasındaki kurumsal örgütlerin de etkisi ile Çin'in Afrika ile ilişkilerinin hem boyutu hem de görünürlüğü son on yılda şaşırtıcı ölçüde artış göstermiştir (Strauss ve Saavedra, 2009, s. 551). Bu esnada Afrika ile ilişskilerin gelişmesinde BM Barışı Koruma Operasyonları'na katılım ile Afrika ülkelerinin Çin’e olan borçlarının silinmesi de iki ayrı dış politika aracı olarak ortaya çıkmıştır. 2004 yılında 558 kişiden oluşan en büyük askerî birliğini Liberya'ya gönderen Çin hükümeti, aynı zamanda 31 Afrika ülkesinin 1.27 milyar dolarlık borcunu silmiştir (Tull, 2006, s.463-464). 2018 y1lında Afrika ile toplam ithalat-ihracat hacmi 204 milyar dolara ulaşan Çin, Afrika'nın en büyük ticaret ortağı haline gelmiştir. Çin ile Afrika arasında atılan kurumsal adımların ve giderek gelişmekte olan siyasi ilişkilerin ekonomik boyutu, Çin'in Afrika'da yürütmüş olduğu dış politikanın en önemli bileşenlerinden birisini oluşturmaktadır. Bu sebeple Çin’in Afrika kriz bölgelerindeki Barışı Koruma Operasyonları'na verdiği desteğin anlaşılması için Çin-Afrika ekonomik ilişkilerinin yapısal özelliklerinin analiz edilmesi bir gereklilik olarak ortaya çıkmaktadır.

$3^{* * *} 2006$ tarihinde ilk kez yayınlanan Afrika Politika Belgesi'nin tamamına ulaşmak için bkz. Foreign Ministry of People's Republic of China, China's African Policy, 2006, 09.20. https://www.fmprc.gov.cn/ zflt/eng/zgdfzzc/t481748.htm (Erişim Tarihi: 02.02.2020)

$4^{* * * *} 2015$ tarihinde yayınlanan ikinci Afrika Politika Belgesinin tamamına ulaşmak için bkz. ChinaDaily, "China's second Africa policy paper", 2015, 12.05. https://www.chinadaily.com.cn/world/ XiattendsParisclimateconference/2015-12/05/content_22632874.htm (Erişim Tarihi: 02.02.2020) 


\section{Afrika-Çin İlişkisinin Yapısal Özellikleri: Enerji ve Ekonomide Tek Taraflı Bağımlılık}

2015 yılında yapılan bir araştırmaya göre Çin’in görünülürlüğünün en fazla olduğu bölgeler arasında \%70 ile Afrika birinci sıradadır (Dollar, 2016, s.3). Afrika ülkelerinde Çin'in sahip olduğu bu olumlu imaj, yapılan büyük ölçekli yatırımlar sonucunda Afrika ülkelerinde azımsanamayacak bir ekonomik iyileşmenin meydana gelmesi ile doğrudan bağlantılıdır. 1980-1990 döneminde yıllık ekonomik büyüme oranı ancak \%2 civarında olan Afrika ülkelerinin Çin ile ilişkilerin yükseldiği 2001-2014 döneminde ulaştıkları büyüme oranları \%5' in üzerine çıkmıştır (African Economic Outlook, 2016, s.20). Çin, Afrika ile ilişkilerinde "gelişim odaklı" bir strateji izlediğini her firsatta dile getirmektedir. Bununla birlikte Çin ile Afrika ülkelerinin ekonomileri arasındaki yapısal farkl11ıklar karşılıklı ticaretin sürekli Çin lehine fazla vermesi ile sonuçlanmaktadır. Çin'in Afrika'dan hammadde ithal ederken bölgedeki ülkelere işlenmiş mamul mal ihraç etmesi ve bunun sonucunda Afrika ülkelerinin ekonomilerinde oluşan dış ticaret açıkları taraflar arasındaki ilişkinin daha yakından incelenmesini gerektirmektedir.

\section{Afrika Ekonomisinde Çin'in Artan Etkinliği}

Küresel ticaret istatistiklerine göre ABD’yi geçerek en büyük ekonomiye sahip olan Çin ile "yeni gelişmekte olan ekonomiler" sınıfında yer alan Afrika ülkeleri arasındaki ekonomik ilişkiler belirli bir takım sınırlılıklara sahiptir. Nitekim küresel mal ihracatında ve ithalatında Çin'in payı \%14.2 ve \%10.3 iken Afrika'nın payı $\% 2.4$ ve $\% 3.4$ oranındadır (WTO, 2016). Bu rakamlara göre küresel ekonomik yapı içerisinde en üst sırada yer alan Çin ile kurulan bağlar, Afrika'yı Çin ekonomisindeki gelişmelere aşırı duyarlı hale getirmiştir. Afrika ekonomisinin Çin piyasasına olan bağımlılığı ve bunun etkileri büyüme ilişkisi, ticaret, mal-hizmet fiyatları ve likidite arzl olmak üzere başlıca dört kanal üzerinden doğrudan hissedilmektedir (African Economic Outlook, 2016, s.26). Sahraaltı Afrika'da 2000'li yılların ortalarında \%7'ye yaklaşan büyüme oranı ile son yıllarda görülen düşük büyüme oranlarında bu karşılıklı-bağımlılığın etkileri hissedilmektedir. Çin'in hızlı büyümeye devam ettiği 2000'li yılların ilk yarısında Afrika bu büyümeden payını almış, Çin ekonomisindeki büyüme yavaşladığında ise Afrika ekonomileri büyüme ivmesini kaybetmiştir (Dollar, 2016, s.viii). Afrika ülkeleri için Çin'in sahip olduğu konumu görebilmek için Afrika ülkelerinin ticaret yaptığı ülkeler sıralamasında Çin'in konumu Tablo 1'de gösterilmiştir. 
Tablo 1

Afrika İhracat ve İthalatında Öne Çıkan Partnerlerin Payları 2000 ve 2014 yılları

\begin{tabular}{|l|c|c|c|c|}
\hline \multirow{2}{*}{ Geleneksel Partnerler } & \multicolumn{2}{|c|}{$\mathbf{2 0 0 0}$} & \multicolumn{2}{c|}{$\mathbf{2 0 1 4}$} \\
\cline { 2 - 5 } & İhracat (\%) & İthalat (\%) & İhracat (\%) & İthalat (\%) \\
\hline AB (25) & 78.3 & 75.4 & 46.7 & 54.3 \\
\hline ABD & 51.3 & 56.4 & 34.0 & 37.4 \\
\hline Yükselen Partnerler & 20.4 & 10.1 & 5.5 & 6.4 \\
\hline Brezilya & 21.7 & 24.6 & 53.3 & 45.7 \\
\hline Çin & 2.0 & 1.3 & 1.7 & 3.0 \\
\hline Hindistan & 4.6 & 4.9 & 18.4 & 15.3 \\
\hline Rusya & 2.4 & 2.1 & 6.1 & 7.4 \\
\hline Türkiye & 0.3 & 1.0 & 1.0 & 0.6 \\
\hline Tayland & 1.9 & 1.3 & 2.4 & 1.0 \\
\hline Toplam (milyar dolar) & 0.6 & 1.2 & 1.5 & 0.8 \\
\hline
\end{tabular}

Kaynak: AFDB, African Economic Outlook 2016: Sustainable Cities and Structural Transformation, s.28.

İlk defa 2009 yılında ABD’yi geçerek Afrika'nın en büyük ticari ortağı olan Çin ile Afrika arasındaki toplam ticaret 2016 yılında 149.1 milyar dolara ulaşmıştır. Bu kapsamda Afrika, Çin'in en önemli ithalat kaynaklarından birisi, denizaşırı yapı projelerinde ikinci büyük pazar ve dördüncü büyük yatırım bölgesi durumundadır (China-Africa Economic and Trade Cooperation, 2013).

Afrika-Çin arasındaki ekonomik ilişkilerin önemli bir bileşeni de Çin tarafından gerçekleştirilen doğrudan yabancı yatırım miktarlarıdır. Afrika’ya yapılan doğrudan yabancı yatırım miktarları arasında Çin'in payı giderek artmış ve 2016 yılında Çin'in kıtadaki toplam yatırımı 36 milyar dolara ulaşmıştır (Kazeem, 2017). Toplamda 32 Afrika ülkesi ile karşılıklı yatırım anlaşması imzalamış olan Çin, Afrika'da faaliyet gösteren şirketlere özel teşvik paketleri uygulamış ve bu sayede hâlihazırda Afrika'da faaliyet gösteren Çinli şirket sayısı iki binin üzerine çıkmıştır. Afrika'daki Çinli şirketlerin çoğunluğu enerji ve altyapı gibi sektörlerde hizmet vermektedir. Bu kapsamda hazırlanan raporlara göre Afrika altyapı sektörüne yapılan finansal desteğin \%80'i Çin tarafindan gerçekleştirilmiştir (AFDB, African Economic Outlook 2016: Sustainable Cities and Structural Transformation, s.61). Karşılıklı ticaret ve doğrudan yatırım oranlarında ortaya çıkan bu değişim, Çin ile Afrika arasındaki enerji ticaretine de yansımış ve enerji güvenliği karşılıklı ilişkilerde stratejik bir unsuru haline gelmeye başlamıştır.

\section{Enerji Kaynaklarının Çeşitlendirilmesi İhtiyacı ve Afrika’nın İstisnai Konumu}

Çin için enerji ithalatının çeşitlendirilmesi enerji güvenliğinin en önemli parametrelerinden biridir. Bu kapsamda enerji kaynaklarını çeşitlendirmek üzere Pekin, Ortadoğu'da İran ve Suudi Arabistan'a, Orta Asya'da ise Kazakistan ve Türkmenistan'a olan bağımlılı̆̆ını Afrika ile dengelemek istemektedir (Karaca, 2012, s.106). Nitekim karşılıklı ticaret ve doğrudan yabancı yatırıma ek olarak Çin ile Sahraaltı Afrika arasındaki ilişkilerin en önemli bileşenlerinden birisini enerji bağları oluşturmaktadır. Dünyada kanıtlanmış toplam petrol rezervinin \% 7.5'ine (BP, Statistical Review of World Energy June 2017) sahip olan Afrika, Çin için Ortadoğu'dan sonra en önemli petrol sağlayıcısı 
bölgelerden birisi konumundadır. 2016 yılı verilerine göre günlük küresel petrol üretiminin \% 8.6'sını gerçekleştiren Afrika, küresel tüketimin yalnızca \% 4.1'ini gerçekleştirirken, Çin küresel üretimin \% 4.3'ünü ve küresel tüketimin \% 12.8'ini gerçekleştirmektedir (BP, Statistical Review of World Energy June 2017). Sahraaltı Afrika ülkelerinin düşük enerji talepleri Çin'in enerji arz kaynaklarının çeşitlendirilmesi politikasında firsat olarak görülmektedir. Bu kapsamda bölge ülkeleri ile yapılan enerji anlaşmaları sonucunda 2016 yılında Afrika, Çin'in toplam enerji ithalatının \% 18'ini karşılayarak Ortadoğu'dan sonra ikinci sıraya yerleşmiştir.

Sahip olduğu zengin doğal kaynaklar sebebiyle Çin'in Afrika'ya yönelik dış politika girişimlerinin temel şekillendiricisi Çin'in ihraç kalemleri karşılığında Afrika'nın sahip olduğu doğal kaynakları kaynağından elde etme stratejisidir. Nitekim Çin'in Afrika'ya yaptığ 1 doğrudan yatırımların \% 50-80'i doğal kaynak yönünden zengin ülkelere yapılmaktadır (Karaca, 2012, s.107). Bu kapsamda Afrika ile sürdürülen enerji iş birliği çeşitli faktörlerin birleşiminin sonucudur. Bunlardan ilki Çin'in Afrika'nın sorunlu bölgelerine enerji kaynaklarına ulaşım karşılığında yatırım ve yardım yapmaya istekli olmasıdır. İkincisi, Çin enerji şirketlerinin kaynak zengini ülkelerde araştırma ve geliştirme imtiyazı karşılığında finansman ve bilgi paylaşımı taahhüdünde bulunmasıdır. Üçüncüsü Çin Enerji Yönetimi'nin Afrikalı hükümetler ve devletlere ait enerji şirketleriyle uzun vadeli anlaşmalar imzalamaya eğilimli olmalarıdır. Dördüncüsü ise Çin'in enerji alanında iş birliği yapmak üzere seçtiği ortakların ABD ve Avrupa'nın ortaklık yapmayı tercih etmediği ülkeler olmasıdır. Bu dört temel özelliğe Çin'in iş birliği yaptığı ülkelerin iç işlerine karışmama ve iş birliği yaptığı ülkeleri eşit seviyede görme politikasının da eklenmesi gerekir. Keza, 2000 yılından beri faaliyette olan Çin-Afrika Forumu'nun giderek önem kazanmasının nedeni bu yaklaşımdır (Karaca, 2012, s.106-107).

Afrika, grafik-1'de görüldüğü gibi Çin'in petrol ithalatında ikinci sırada yer almakla birlikte Afrika'dan yapılan enerji ithalinin bölge içerisinde eşit dağıldığı söylenemez. Bölgeden Çin'e ulaşan ithal petrolün \%87'si Batı Afrika'dan, \%10'u Doğu ve Güney Afrika'dan ve yaklaşık \%3'ü Kuzey Afrika'dan sağlanmaktadır (BP, Statistical Review of World Energy June 2017). Halihazırda 11'den fazla Afrika ülkesinde petrol hisselerine sahip olduğu açıklanan Çinli petrol şirketleri, yatırım yapacakları ülkelerin seçiminde; enerji piyasasında Batılı ülkelerin hâkim olmadığı veya petrol sanayisinin yeni gelişmekte olduğu bölgeleri öncelikli olarak tercih etmektedir (Tull, 2006, s.469). Enerji ithalinin yanında petrol kaynaklarını arama, çıkarma ve işleme faaliyetlerine yönelik yatırımların en fazla yapıldığı ülkeler Afrika'daki kanıtlanmış petrol rezervlerinin \%10'una sahip olan Angola ve \%5'ine sahip olan Sudan (Güney Sudan ve Sudan) üzerinde yoğunlaşmıştır (IEA, Africa Energy Outlook 2014). 


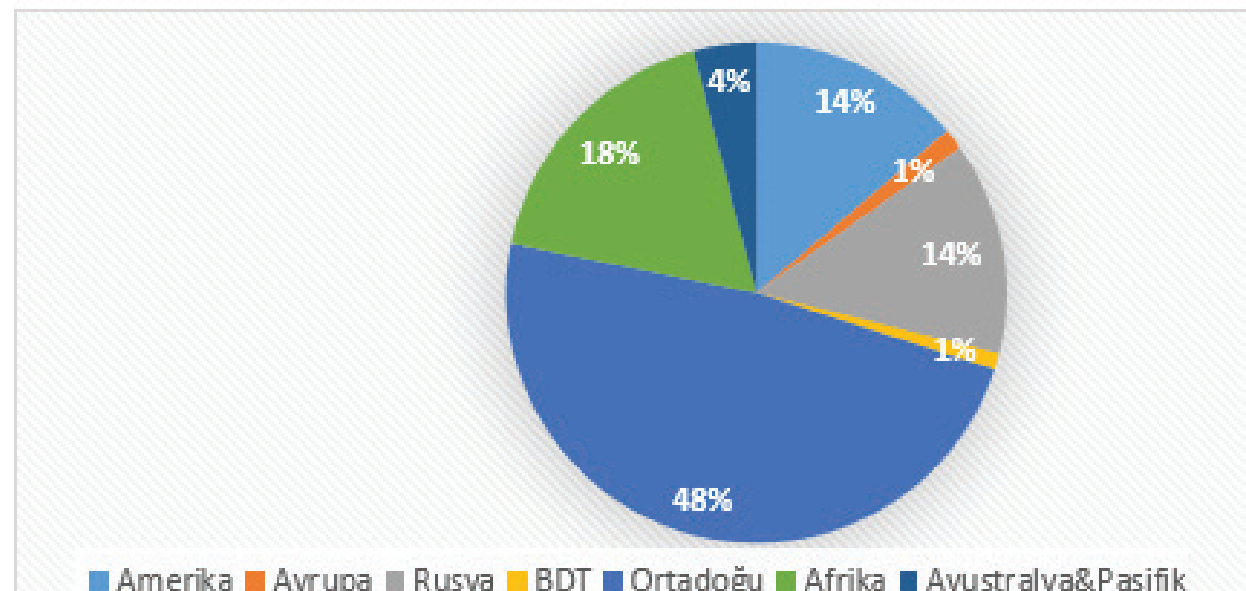

Grafik 1. Çin'in Petrol İthal Ettiği Bölgeler- 2016

(Kaynak: BP, Statistical Review of World Energy June 2017,

http://www.bp.com/content/dam/bp/en/corporate/pdf/energy-economics/statistical -review-2017/bp-statistical-review-of-world-energy-2017-full-report.pdf, (e.t. 07.09.2017))

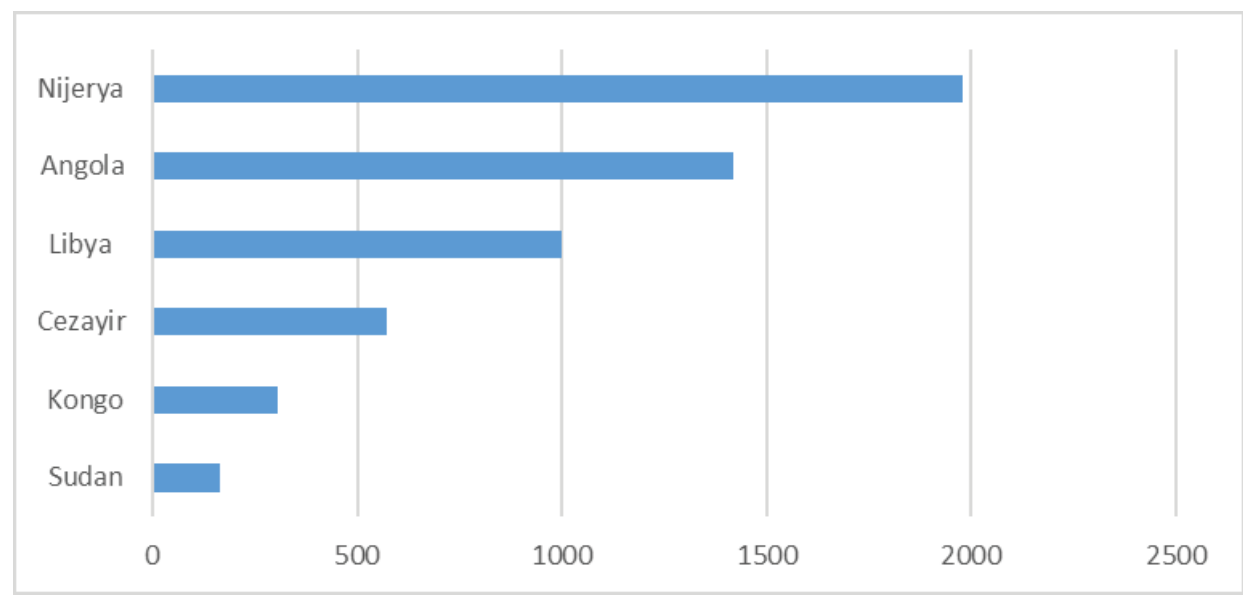

Grafik 2. Çin Petrol İthalatında Afrika Ülkelerinin Payı (1980-2018) (bin varil/gün) Kaynak: China Crude Oil Exports (1980-2018), https://www.ceicdata.com/en/ indicator/china/crude-oil-exports (e.t. 09.11.2019).

Çin'in toplam petrol ithalatında Afrika ülkelerinin sahip olduğu oranlar Grafik 2'de verilmiştir. Buna göre Çin'in Afrika'dan gerçekleştirmiş olduğu petrol ithalatında Nijerya, Angola, Libya, Cezayir, Kongo ve Sudan \%90 oranında bir ağırlığa sahip bulunmaktadır (Gamache vd. 2013, s.1). Grafikteki verilerden de görüldüğü üzere, Sudan ve Güney Sudan (Darfur), mevcut siyasi istikrarsızlıklar ve çözümlenemeyen krizler sebebi ile petrol ihracatı sıralamasında Angola ve Kongo gibi ülkelerden sonra gelmektedir. Bu sıralamaya göre Angola, Suudi Arabistan'dan sonra Çin'in en fazla petrol ithal ettiği 
ülkelerin başında gelmekte fakat Güney Sudan toplam ham petrol ihracatının \%95'ini yalnızca Çin'e gerçekleştirmektedir (Vasquez, 2019 ve Dahir, 2019). Bununla birlikte Çin'in Afrika'dan ithal etmiş olduğu toplam ham petrol miktarında Sudan'ın oranı yalnızca \%2 düzeyindedir (Zürcher, 2019, s.44). Bu kapsamda Sudan ve Güney Sudan (Darfur) arasındaki siyasi krizde Pekin' in BM ile iş birliği yaparak krizin çözümüne katk1 sağlaması ve BM Barış Koruma Operasyonları'na katılım sağlamış olması, Çin’in tek stratejik kaygısının enerji olmadığını göstermektedir.

\section{Çin'in BM Barışı Koruma Operasyonları'na Katkısı ve Afrika Kriz Bölgeleri Üzerindeki Dış Politikası}

Çin'in uluslararası sistem içerisinde geliştirmiş olduğu güvenlik ilişkileri "geleneksel büyük bir güce özgü” ittifaklar kurma, ülke dışında üsler edinme, yurtdışına asker gönderme, donanmasını dünyanın her yerinde hâkim kılma, başkalarına zor kullanma ve çatışmalara doğrudan katılma şeklinde gelişmemiştir. Çin son yirmi yıldır askerî yeteneklerini geliştirmiş olmakla birlikte uluslararası barış misyonlarına katılımını sınırlı tutmuştur (Shambaugh, 2016, s. 293). Gerçekten Çin'in devlet egemenliği, güç kullanımı ve müdahale karşıtlığı, iç işlere öncelik verme gibi normatif ilkeleri, Pekin yönetiminin aktif bir barış koruma destekçisi olmasını engellemiştir. (He, 2007, s.9). Bununla birlikte son yıllarda Çin'in BM Barış Koruma Operasyonları'na karşı politikalarında önemli bir dönüşüm yaşanmakta, bu da uluslararası çevrelerde ciddi bir "kafa karışıklığı" yaratmaktadır. Son beş yıl içerisinde Çin, BM Barışı Koruma Operasyonları'nı yürüten misyonlara beşeri ve finansal katkısını önemli ölçüde artırmıştır. 2018 yılında Barış Koruma Operasyonları'na yapılan toplam finansal katkının yaklaşı \% 10'u Çin tarafından gerçekleştirilmiştir. Bu finansal destek ile Çin, BM Barışı Koruma Operasyonları'na ABD'den sonra en fazla katkı sağlayan ülke konumuna yükselmiştir (Department of the Secretary of Defense, 2018). Xi Jinping 2015'te New York'ta düzenlenen Barış1 Koruma Liderler Zirvesi'nde -takip eden beş yıl içerisinde yapılmak üzere- barış koruma operasyonları için 1 milyar dolarlık bir taahhütte bulunmuştur. Finansal desteğinin yanında Çin 8,000 askerini BM barış koruma operasyonlarında daimi personel olarak görevlendirmek üzere eğitmiştir. Bu stratejik manevraları sebebiyle BM Genel Sekreteri António Guterres, Çin için "güvenilir arabulucu" ve "köprü-inşa edici” söylemlerini kullanmıştır. (Pauley, 2018). Nitekim 2018 yılına gelindiğinde Çin, BM Güvenlik Konseyi'nin beş daimi üyesi arasında BM Barışı Koruma Operasyonları'na en fazla askerî birlik gönderen ülke konumuna yükselmiştir (Fang vd., 2019, s.183).

Çin'in geleneksel dış politika ilkelerine bağlı ve uluslararası sisteme uyum sağlamayacağına dair yaygın ön kabule rağmen Pekin'in BM Barış Koruma Operasyonları'na aktif şekilde katılma yönünde politika geliştirmesi, tarihsel süreç bütünsel bir bakış açısıyla incelendiğinde anlam kazanmaktadır. Çin'in BM Barışı Koruma Operasyonları'na katkısı dört alt dönemde incelenebilmektedir. Birinci dönemi oluşturan 1981-1988 dönemi boyunca Çin'in operasyonlara karşı tutumu bu operasyonların büyük güçlerin emperyalist müdahaleleri olduğuna yönelik ideolojik yaklaşımı ile şekillenmiş ancak 1988 yılında BM Barışı Koruma Operasyonları Özel Komisyonu üyesi olmasıyla birlikte Pekin'in politikaları önemli ölçüde değişmeye başlamıştır. Nitekim ikinci dönemi oluşturan 1989-1998 yıllarında Pekin, geleneksel bakış açısı ile küresel sistem içindeki 
değişen konumu arasında bir denge oluşturmaya çalışmış ve BM operasyonlarına karşı daha esnek politikalar izlemiştir. 1989 yılında ilk kez Namibya'daki BM Geçiş Dönemi Yardım Grubu (The United Nations Transition Assistance Group-UNTAG) birliklerine sivil gözlemciler göndermek yolu ile BM Barışı Koruma Operasyonu'na katılım sağlayan Çin, 1997 Guatemala ve 1999'da Makedonya'daki barışı koruma faaliyetlerini veto etmiştir. Bu vetoların temel sebebi ise her iki ülkenin de Tayvan'ı resmi olarak tanıyor olmalarından kaynaklanmıştır.1999-2003 dönemi Çin'in BM Barışı Koruma Operasyonları'na karşı desteğinin ve katılımının önemli ölçüde arttığ1 ancak henüz askerî birliklerin gönderilmediği yıllar olmuştur. 2004'den günümüze kadar gelen dördüncü dönemde ise Çin, BM Barışı Koruma Operasyonları'na en fazla askerî birlik gönderen BM Güvenlik Konseyi daimi üyesi ve en fazla finansal katkı sağlayan ikinci ülkesi konumuna gelmiştir (Zürcher, 2019, s.16). Bu kapsamda 1970’li yılların BM Barışı Koruma Operasyonları'na karşı derin bir muhalefet ile şekillendiğini, 1980 ve 1990'l y ylların operasyonlara reaktif katılımın sağlandığı ve 2000'li yıllardan sonra operasyonlara karşı tutumun aktif katılım yönünde değişim gösterdiği görülmektedir (He, 2018, s.271).

Çin'in BM'ye kabul edilmesinden sonraki ilk on yıl içerisinde Barışı Koruma Operasyonları'nın oylamalarına katılmaya veya Barışı Koruma Operasyonları'na ekonomik fon ve personel sağlamaya karşı çekimser kaldığı ve ilk finansal desteğini ancak 1982'de gerçekleştirdiği görülmektedir (Courtney, 2016, s.1). Çin'in BM askerî operasyonlarına ilişkin politikaları üzerine odaklanan çalışmalar; 1970'lerde Pekin'in BM operasyonlarına muhalefet ve katılmama prensibi temeline dayandığını, 1980'lerde operasyonları onaylama fakat katılmama, 1990'larda ise destekleme ve katılma yönünde bir gelişim olduğunu göstermektedirler (Holslag, 2008, s.73). Buna göre Çin, BM Barışı Koruma Operasyonları'na ilk personel desteğini 1989 yılında gerçekleştirmiştir (Cho, 2018, s.2). Tablo.2'de Çin'in bugüne kadar katılım sağladığı tüm BM Barışı Koruma Operasyonları ve katılım sağladığı yıllar gösterilmiştir. 2001 yılının sonunda Çin, "çatışmaların önlenmesi, barışın inşası ve barış koruma operasyonları" arasında giderek artan karşılıklı bağımlı bir yapı olduğunu kabul etmiştir. Bununla birlikte Çin’in egemen devletlerin iç işlerine müdahaleyi kabul etmesi için ön koşulu; "hedef ülkelerin rızalarının” olmasıdır (Stähle, 2008, s. 650).

Tablo 2

Çin 'in Katılım Sağladı̆̆ BM Barışı Koruma Operasyonları (1990-2019)

\begin{tabular}{|l|c|c|}
\hline BM Barışı Koruma Operasyonu & Ülke & Katıldı̆̆ı yıllar \\
\hline UNTSO & İsrail-Kudüs & Nisan 1990- devam ediyor \\
\hline UNIKOM & Irak-Kuveyt & Nisan 1991 - Ekim 2003 \\
\hline MINURSO & Batı Sahara & Eylül 1991- devam ediyor \\
\hline UNTAC & Kamboçya & Aralık 1991- Eylül 1993 \\
\hline ONUMOZ & Mozambik & Haziran 1993 - Aralık 1994 \\
\hline UNMIL & Liberya & Ekim 2003 - Şubat 2018 \\
\hline UNSMA & Afganistan & Mayıs 1998 - Ocak 2000 \\
\hline UNAMSIL & Sierra Leone & Ağustos 1998 - Aralık 2005 \\
\hline UNMISET & Doğu Timor & Ocak 2000 - Temmuz 2006 \\
\hline UNMEE & Etiyopya ve Eritre & Ekim 2000 - Ağustos 2008 \\
\hline UNMIBH & Bosna-Hersek & Ocak 2001 - Ocak 2002 \\
\hline
\end{tabular}




\begin{tabular}{|c|c|c|}
\hline MONUC & Kongo & Nisan 2001- devam ediyor \\
\hline UNMIL & Liberya & Ekim 2003 - Mart 2018 \\
\hline UNAMA & Afganistan & Ocak 2004 - May1s 2005 \\
\hline UNOCI & Fildişi Sahili & Mart 2004 - Haziran 2017 \\
\hline UNMIK & Kosova & Nisan 2004 - Aralık 2008 \\
\hline MINUSTAH & Haiti & Mayıs 2004 - Ekim 2017 \\
\hline ONUB & Brundi & Haziran 2004 - Eylül 2006 \\
\hline UNMISS & Sudan & Nisan 2005- devam ediyor \\
\hline UNIFIL & Lübnan & Mart 2006- devam ediyor \\
\hline UNMIT & Timor-Leste & Ekim 2006 - Kasım 2012 \\
\hline UNIOSIL & Sierra Leone & Şubat 2007 - Şubat 2008 \\
\hline UNAMID & Darfur, Sudan & Kasım 2007- devam ediyor \\
\hline MINUSMA & Mali & Ekim 2013-devam ediyor \\
\hline UNFICYP & Kibris & Şubat 2011- devam ediyor \\
\hline
\end{tabular}

Kaynak: Permanent Mission of the People's Republic of China to the UN, http://www.china-un.org/eng/zt/wh/ t534321.htm (e.t. 21.02.2019)

Tablo 2'de verilen ve Çin Savunma Bakanlığı raporlarına dayanan bilgilere göre Çin, 1990 yılından bugüne kadar toplamda yirmi beş BM Barışı Koruma Operasyonu'na yaklaşık 36.000 personel ile destek sağlamıştır (MoD, 2019; ChinaDaily, 2018).

Tablo 3

Çin'in BM Misyonlarına Personel Desteği-Ocak 2019

\begin{tabular}{|l|c|c|c|c|c|c|}
\hline BM BKO & Ülke & Askerî Birlik & Polis Gücü & Görevli & Uzman & Toplam \\
\hline UNAMID & Darfur-Sudan & 365 & & 5 & & 370 \\
\hline UNMISS & Güney Sudan & 1031 & 12 & 19 & 5 & 1067 \\
\hline MINURSO & Batı Sahara & & & & 13 & 13 \\
\hline MINUSMA & Mali & 395 & & 1 & & 396 \\
\hline MONUSCO & Kongo Dem. Cum. & 218 & & 4 & 9 & 231 \\
\hline UNIFIL & Lübnan & 410 & & 9 & & 419 \\
\hline UNTSO & Kudüs & & & & 6 & 6 \\
\hline UNFICYP & Kibris & & 6 & & & 6 \\
\hline Toplam & & 2419 & 18 & 38 & 33 & 2508 \\
\hline
\end{tabular}

Kaynak: UNPKO, https://peacekeeping.un.org/sites/default/files/5_mission_and_country_12.pdf (e.t.20.02.2019)

Tablo 3'de ise Çin'in 2019 Ocak ayı itibari ile destek vermekte olduğu Barışı Koruma Operasyonları ve bu operasyonlarda görevlendirmiş olduğu personelin sınıfı gösterilmiştir. 2019 Ocak ayında Çin’in BM Barışı Koruma Operasyonları'nda toplam 2508 personeli bulunmakta ve bu rakamlarla Çin, operasyonlara katkı sağlayan ülkeler arasında 11. Sırada yer almaktadır (UNPKO, Troops and Police Contributors by Country, 2017). Çin'e göre uluslararası müdahale ancak uluslararası barış ve güvenlik tehdit altındaysa veya söz konusu devlet müdahaleyi onaylıyorsa meşru görülmektedir (Tüter, 2018, s. 347). Bu ilkeyi destekleyecek şekilde Kongo, Liberya, Fildişi Sahili, Haiti, Brundi ve Sudan'daki Barışı Koruma Operasyonları'nın bulundukları ülkelerde güç kullanma yetkisi, (S/ RES/1291, S/RES/1509, S/RES/1528, S/RES/1542, S/RES/1545, S/RES/1590 numaral1 BM kararları) yalnızca BM personeli ve onların hareket özgürlüklerinin desteklenmesi, 
ağır fiziksel şiddet altındaki sivillerin korunması durumları ile sınırlandırılmıştır (Stähle, 2008, s. 647).

Çin'in 2000'li yıllardan itibaren BM Barışı Koruma Operasyonları'na aktif şekilde katılmaya başlaması, ülke içerisinde yasal düzenlemenin yapılmasını gerektirmiştir. $\mathrm{Bu}$ kapsamda ilk kez Aralık 2001'de Çin, BM Barış Koruma Operasyonları'na personel gönderimi ile ilgili koordinasyonu sağlamak üzere Ulusal Savunma Bakanlığı bünyesinde Barışı Koruma İlişkileri Departmanı'nı kurmuş, 2002 Ocak ayında BM Hazır Barış Gücü Düzenlemeleri Sistemi (UN Stand-by Arrangement System-UNSAS)'a resmî olarak katılmış ve BM Sekreterliği'ne operasyonlarda görevlendirebileceği personel bilgilerini kayıt ettirmiştir. Üye devletlerin, BM Barışı Koruma Operasyonları'na belirli bir zaman içerisinde sağlayabilecekleri kaynakların şartlarını içeren UNSAS'a kayıt yaptırması ve iç hukuksal düzenlemelerini bu sisteme uyarlaması Çin hükümetinin BM Barışı Koruma Operasyonları'na daha aktif şekilde katılmasını hızlandırmıştır (Masuda, 2011, s. 12-13).

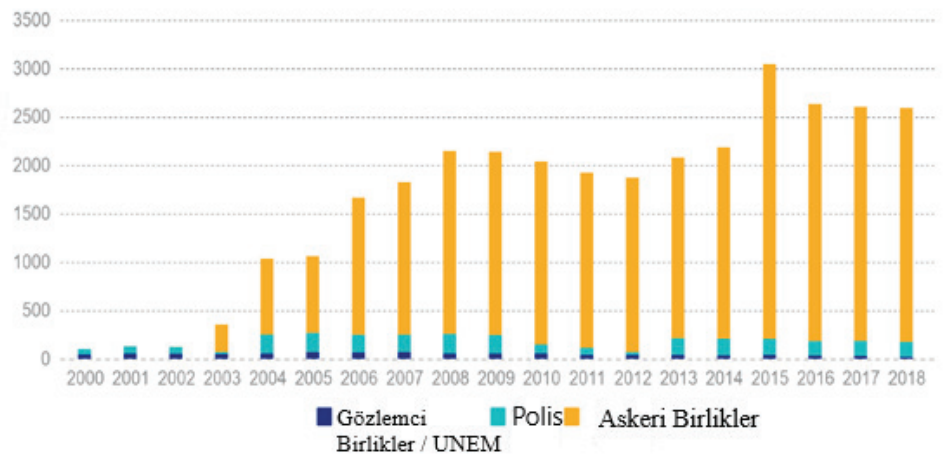

Grafik 2. Çin'in Barışı Koruma Operasyonları'na Katkısı (2000-2018)

(Kaynak: ISDP, 2018, s.3)

Grafik 2'deki verilere bakıldığında Çin'in UNSAS'a kayıt yaptırdığı tarih olan 2002'den önce BM Barışı Koruma Operasyonları'na yalnızca gözlemci birlikler ve polis gücü katıldığı, fakat 2002'den sonra askerî birlikler ile daha aktif şekilde katılım sağladığı görülmektedir. Çin Afrika, Asya, Ortadoğu, Avrupa ve Amerika kıtası dâhil olmak üzere dünyanın her bölgesine personel göndermiştir. Ancak, sadece altı Barışı Koruma Operasyonu'na Çin ordusu askerî personelini sevketmiştir: Kamboçya, Kongo Demokratik Cumhuriyeti, Liberya, Sudan, Lübnan ve Darfur. Bu sıralamanın gösterdiği gibi Çin ordusu mensubu askerî personelin en çok katıldığı Barışı Koruma Operasyonları Afrika'dadır (Matsuda, 2016, s. 61-62). Dahası Pekin yönetiminin en büyük askerî birliklerini göndermiş olduğu Kongo, Liberya ve Sudan kriz bölgeleri diğer büyük güçlerin katkıları karşısında Çin'in arabuluculuk ve çatışma çözümü gibi diplomatik çabalarının da ön plana çıktığı bölgeler olmuştur (Ayenagbo vd., 2012, s.22).

Çin'in Afrika ülkeleri ile askerî iş birliği; askerî ve teknik personele yönelik eğitim programları, temel donanım ile silah satışlarını kapsamaktadır. 1990'ların sonunda Mozambik ordusuna üniforma, eğitim ve bazı hafif donanımlar sağlayan Çin'in Zimbabwe'ye savaş uçakları, Angola ve Mali'ye helikopterler, Namibya ve Sierra 
Leone'ye hafif silahlar tedarik ettiği ve Etiyopya-Eritre savaşında her iki tarafa en az 1 milyar dolarlık silah satışı yaptığı rapor edilmektedir. Çin tarafından Sudan'a yapılan silah transferi 2010 y1lında 17 milyon dolar iken bu rakam 2017 ve 2018 yıllarında 32 milyon dolara ulaşmıştır (SIPRI, 2019). Bu rakamlar ile Rusya'yı geçerek Sudan'ın en büyük silah sağlayıcısı durumunda olan Çin, aynı zamanda Liberya'da 600, Demokratik Kongo Cumhuriyeti’nde ise 218 arabulucu görevlendirmiştir (Alden, 2005, s.151-152).

Çin tarafından Afrika'nın enerji zengini bölgeleri başta olmak üzere gerçekleştirilen ekonomik ve finansal yardımları, enerji ticareti ve altyapı yatırımları ile silah transferi Pekin'in bölgede etkin bir güç olarak kabul edilmesi sonucuna yol açmıştır. Bunun en önemli göstergelerinden bir tanesi ise Afrika kriz bölgelerindeki çözüm süreçlerinde gerek yerel unsurların ve gerekse uluslararası örgütlerin Çin'in iş birliğine ihtiyaç duymaları olmuştur. Bu kapsamda Çin'in Sudan ve Güney Sudan arasındaki krizin çözüm sürecindeki rolü ve BM Barışı Koruma Operasyonları'na desteği analiz edilmesi gereken bir örnek olay konumundadır.

\section{Çin Dış Politikasında İlkesel Dönüşüme Doğru: Darfur Sorunu ve Anti-Müdahale Politikasının Değişimi}

Sudan'ın güney bölgesinde çoğunlukla Hristiyan nüfustan oluşan hükümet karşıtı grup ile Sudan hükümeti arasında çatışmalar başladıktan sonra Sudan yönetimi süreçten olumsuz şekilde etkilenmiş ve giderek istikrarsızlaşmıştır. 2003 Şubat ayında Darfur Özgürlük Cephesi (Darfur Liberation Front-DLF) silahlı bir ayaklanmaya öncülük etmiş, buna karş11ık Janjaweed adı verilen ve Sudan hükümeti tarafından desteklendiği ileri sürülen bir Arap milis kuvveti, Darfur'un Arap olmayan halkına karşı saldırılar başlatmıştır. Savaşan taraflar arasında Afrika Birliği, arabulucu rolü oynamaya çalışsa da kriz hızla tırmanarak uluslararası boyut kazanmıştır. 2004 yılında taraflar arasında ateşkes imzalanmasına ve bir gözlemci Afrika Birliği heyetinin Darfur'a sevk edilmesine karar verilmesine rağmen Afrika Birliği'nin yetersiz askerî kapasitesi ve finansal desteği sebebiyle Afrika Birliği tarafından gözlenen ateşkes anlaşması başarıya ulaşamamıştır. Darfur'daki durum şiddetini artırdıkça BM tarafindan 2003-2007 arasında toplam 21 adet Güvenlik Konseyi Kararı kabul edilmiştir. Bununla beraber Çin, krizin çözümüne ilişkin BM kararlarının görüşüldüğü oylamaların bazılarında çekimser kalmıştır. (Masuda, 2011, s. 21).

Çin yönetimi 1990'lı yıllardan itibaren ilişkilerinin yoğunlaştı̆̆ 1 Sudan'da ilk kez Darfur Krizi esnasında bölgesel ve uluslararası boyutlarda eleştirilere maruz kalmıştır. Darfur Krizi'ni Sudan hükümetinin iç sorunu olarak gören ve geleneksel iç işlerine karışmama prensibi etrafında şekillenen dış politika anlayışı ile hareket eden Çin, Pekin Olimpiyatları'nın boykot edilmesi tehlikesi ile karşı karşıya kaldığında mevcut politikasında önemli bir değişime gitmek zorunda kalmıştır. Dolayısıyla Darfur Krizi Çin'in bölgesel ve uluslararası çıkarlarını dengelemek ve geleneksel dış politika ilkelerini gözden geçirmek zorunda kaldığı bir kriz olması açısından bir dönüm noktası olmuştur.

Sudan ve Çin arasındaki diplomatik ilişkiler 1959'da resmen başlamış olmakla birlikte iki ülke arasındaki ilişkiler 1970'lere kadar sınırlı kalmıştır (Shinn, 2009, s.87). 1970'li yıllarda Sudan'a ilk kredi önerisini gerçekleştiren Çin ile Sudan arasında ilişkiler bu tarihten sonra gelişmeye başlamış 1990'da Sudan devlet başkanı Ömer el-Beşir'in Pekin'i ziyaretinden sonra İran tarafından finanse edilen Sudan, Çin silahlarını satın 
almaya başlamıştır. Çin ile bu ilişkiler başlamadan yıllar öncesinde Sudan, Batı tarafından insan hakları ihlalleri ve teröre destek verdiği gerekçesiyle izole edilmiştir. Bu dönemde Sudan'ın uluslararası sistemden izole edilmesine yönelik politikalar, Hartum yönetiminin Çin ile yakınlaşmasını hızlandıran temel faktör olmuştur (International Crisis Group, "China's Foreign Policy Experiment in South Sudan”, 2017, s.1.). Nitekim Chevron'un Sudan'daki iç çatışmalar sebebiyle petrol üretimini durdurması Sudanlı yöneticilerin Chevron'un yerini alması için 1994'de Çin'e teklifte bulunmalarına yol açmış (Shinn, 2009, s.87) böylece Çin ile Sudan arasındaki enerji bağlarının temeli atılmıştır.

Çin, 1960'ların sonundan itibaren Sudan'a uçak ve silah satışı yapmasına rağmen Darfur krizi başladığında bu silah satışlarına devam etmesi uluslararası aktörler tarafından eleştirilmesine yol açmıştır. 2003-2006 yılları arasında Sudan'ın en büyük silah tedarikçisi olan Çin'in bu dönemde yıllık en az 14 milyon dolarlık satış yaptığg bilinmektedir. 2004 yılında BM Güvenlik Konseyi Darfur'da devlet-dışı aktörler ve kişilere her türlü silah satışını yasaklamış ve bir yıl sonra bu yasağı Sudan silahlı kuvvetlerine de uygulayacak şekilde genişletmiştir. Bununla birlikte Çin, bu ambargoya uymamış ve silah satışına devam etmiştir (Shinn, 2009, s.90). Darfur krizi başladıktan sonra BM Güvenlik Konseyi tarafından 2004-2006 yılları arasında yapılan görüşmelerde Çin, Sudan yönetimini insan hakları ihlalleri ile suçlamaktan, Hartum hükümetine karşı sert eleştirilerde bulunmaktan ve Sudan'a uygulanması kararlaştırılan ambargolara katılmaktan kaçınmıştır. Sudan Hükümeti'nin, Batı Darfur bölgesinde çatışan Arap grupların silahsızlandırılmasında başarısız olması durumunda BM Güvenlik Konseyi'nin yaptırım uygulama kararına yönelik oylamada, Çin çekimser kalmıştır (Tüter, 2018, s. 348). Bu süreçte 2006 yılı, Çin'in Darfur sorununa yaklaşımında önemli bir dönüm noktası oluşturmaktadır. Nitekim bu tarihe kadar Çin yönetimi, Darfur sorununun Sudan'da çatışan taraflar arasında ve Afrika Birliği gibi yerel örgütlerin kontrolü altında çözülmesi gerektiğini vurgulamıştır. Dönemin Afrika Birliği Başkanı Alpha Konaré’nin yürüttüğü görüşmeler sonucunda, Darfur sorununun tarafları arasında ateşkes anlaşması imzalanmış ve bu anlaşma kapsamında Afrika Birliği Sudan Misyonu (African Union Mission in Sudan$A M I S$ ) adı altında ateşkesi korumakla görevli gözlemci bir askerî gücün oluşturulması kararlaştırılmıştır (Ekengard, 2008, s.14).

Çin yönetimi, Darfur sorununa ilişkin olarak BM tarafından oluşturulacak bir Barışı Koruma Operasyonu'a karşı çıkmış ve öncelikle Afrika Birliği Sudan Misyonu'nun desteklenmesini önermiştir. Sudan'a karşı güç kullanımı veya ekonomik yaptırım uygulanması olasılıklarını kabul etmekle birlikte Güvenlik Konseyi'nin 1564 sayılı ekonomik yaptırımlara ilişkin ve 1706 sayılı Darfur'da Barışı Koruma Operasyonları'nı yürütücek bir misyonun konuşlanmasını içeren kararları karşısında çekimser kalmıştır. Çin'in Darfur'da BM misyonunun konuşlanmasına olan çekincesinin temel gerekçesi, Sudan hükümetinin bu konudaki rızasına yer verilmemiş olmasıdır (Masuda, 2011, s. 22). Ancak Sudan Hükümeti'nin rızası olması durumunda sürecin BM gücüne bırakılabileceğini söyleyen Çin yönetimi, 2006 yılında politika değişikliğine gitmek zorunda kalmıştır. Darfur sorununa ilişkin yürütmüş olduğu politika sebebiyle, uluslararası çevreden giderek yükselen bir tepki almaya başladığında ve 2008 Pekin Olimpiyatları'nın boykot edilmesi gündeme geldiğinde Pekin yönetimi, BM Barışı Koruma Operasyonu konusunda daha ılımlı bir politika izlemeye başlamıştır. Yapılan görüşmeler sonucunda 2007 yılında 
BM-Afrika Birliği ortak gücü müdahale için yetkilendirilmesine karar verilmiş ve Çin yönetimi, Sudan devlet başkanı Ömer el-Beşir'in BM misyonunu kabul etmesini sağlamıştır (Shinn, 2009, s.93). Yani Çin, kararları veto etmemiş fakat oy kullanmakta çekimser tavır takınmıştır.

Çin'in Darfur krizinin çözüm mekanizmalarına aktif şekilde dâhil olması, uzun yıllardır sürdürülen anti-müdahaleci dış politikadan uzaklaşmanın ve çok taraflı barış ve güvenlik çabalarına katılmasının ilk örneklerinden birisini oluşturmaktadır. Çin'in Hartum ile petrol endüstrisi üzerindeki yakın ilişkilerinin varlığı, 2003 yılında Darfur'da silahlı gruplar hükümete karşı ayaklandığında, Çin'in Batı tarafından soykırımı desteklemekle suçlanmasının temel gerekçesini oluşturmuştur (International Crisis Group, "China's Foreign Policy Experiment in South Sudan”, 2017, s.4). Artan eleştiri ve tepkiler üzerine Darfur savaşında herhangi bir sorumluluğu olmadığını belirten Çin yönetimi, Mayıs 2007'de Liu Guijin'i Darfur sorunu ve Afrika ilişkilerinden sorumlu özel temsilci olarak atamıştır. 2007 yılı boyunca yapılan basın açıklamaları ve özel mesajlar yoluyla Çin, Sudan Devlet Başkanı Ömer el-Beşir’i BM Barışı Koruma Operasyonları'nı yürütecek BM misyonunun ülkeye konuşlanması konusunda ikna etmiştir. Ayrıca 2005 yılında Kapsamlı Barış Anlaşması (Comrehensive Peace Agreement-CPA)'nın uygulamaya konması esnasında Çin, petrol gelirlerinin Hartum ve Güney Sudan bölgesel hükümeti arasında paylaşılması için yapılan görüşme ve müzakereleri desteklemiş ve etkili bir arabulucu rolü üstlenmiştir. Darfur sorununda yürüttüğü diplomasi ve arabulucu rolü ile Çin, bölgesel ve uluslararası krizlerin çözümünde etkili olabileceğini göstermiştir (International Crisis Group, “China’s Foreign Policy Experiment in South Sudan”, 2017, s.5). Böylelikle, Darfur sorununda Sudan hükümetinin barış koruma birliklerini kabul etmesi için Çin'in bu üke üzerindeki nüfuzunu kullanması yönünde var olan uluslararası bir beklentiye uygun olarak Çin, zirve toplantıları ve özel temsilcilik oluşturma yoluyla “arabulucu diplomasi” uygulamaya başlamıştır. (Masuda, 2011, s. 25).

Bununla birlikte Darfur sorunu, Çin yönetimi için ulusal çıkarları ile uluslararası iş birlikleri arasında bir "orta yol” bulmasını gerektirecek çelişkiler yaratmıştır. Pekin yönetimi bir yandan devletlerle ilişkilerinde egemenliğe saygı ve iç işlerine karışmama ilkelerini temel alırken diğer yandan uluslararası örgütlere katılma ve çok taraflı yapıcı faaliyetlere uyum sağlama ilkesine yönelmek istemektedir. Darfur sorununda Çin, Hartum yönetimini savaş suçları işlemesi konusunda desteklemekle eleştirilmiş ve Sudan'daki şiddet olayları Çad'a yayılmaya başladığında Çin'in içinde bulunduğu durum daha da sıkıntılı bir hal almaya başlamıştır (Holslag, 2009, s.25). Nitekim Çin, Sudan'ın komşu ülkeleri olan Etiyopya, Libya, Çad ve Orta Afrika Cumhuriyeti'nde çeşitli enerji anlaşmalarına sahip olduğu için Darfur'dan çevre ülkelere yayılacak bir istikrarsızlık Çin için enerji güvenliğinin tehlikeye girmesi anlamına gelmiştir (Holslag, 2008, s.75).

Darfur sorunundaki politikaları ve sonuçları değerlendirildiğinde Çin, krizin ilk dönemlerinde "iç işlerine karışmama" söylemi ile Sudan hükümetine karşı alınan uluslararası yaptırımlar karşısında çekimser kalmış ve bu politika uluslararası çevreden ciddi tepkiler aldığında Çin, uluslararası desteğini kaybetmemek için politika değişikliğine gitmiştir. Özellikle Sudan Devlet Başkanı El-Beşir ile yaptığı görüşmeler sonucunda BM Barışı Koruma Operasyonu'na onay verilmesini sağlaması ve Sudan'daki taraflar arasında yürüttüğü arabulucu rolü sonrasında uluslararası tepki ve eleştirileri bertaraf 
etmiştir. Bu kriz sonrasında Çin, izole edilmiş olmaktan ziyade Afrika Birliği, Birleşmiş Milletler ve Arap Ligi gibi çeşitli bölgesel ve uluslararası örgütlerdeki güvenilirliğini pekiştirmiştir (Holslag, 2008, s.84).

\section{BM Barışı Koruma Operasyonları'na Aktif Katılım: Darfur ve Güney Sudan Örnekleri}

1956'da Mısır ve İngiliz ortak yönetiminden bağımsızlığını kazandıktan sonra Sudan çeşitli iç savaş ve kriz dönemlerinden geçmiştir. Yaşanan çatışmalardan en önemli ikisi Sudan ve Güney Sudan arasında 1955-1972 ve 1983-2005 dönemlerinde meydana gelmiştir. İkinci iç savaş sonrasında Güney Sudan'a özerklik veren Kapsamlı Barış Anlaşması ile petrol gelirlerinin kuzey ve güney arasında ortak şekilde dağıtılmasına karar verilmiş ve Güney Sudan'ın bağımsızlığı için bir takvim belirlenmiştir. Nihayetinde 2011'de yapılan referandumda Güney Sudan bağımsız bir devlet olarak Güneydoğu Afrika'da yerini almıştır (EIA, Country Analysis Brief: Sudan and South Sudan, 2014, s. 4).

2011 y1lında gerçekleşen ayrılıktan önce Sudan küresel dünya petrol rezervinin \%5'ine sahip olmakla birlikte Sudan petrol üretiminin \%75'i Güney Sudan'daki petrol yataklarından sağlanmaktadır (Large, 2016, s.37). OPEC üyesi olmayan Birleşik Sudan, Afrika'da ikinci büyük petrol üreticisi olmakla birlikte iç çatışmalar sonrasında ülkenin petrol üretimi ciddi bir kesintiye uğrayarak petrol gelirleri $\% 60$ oranında düşüş göstermiştir (EIA, Country Analysis Brief: Sudan and South Sudan, 2014, s. 1). Sudan ve Güney Sudan'ın fiilen ayrılmasından sonra petrol üretimi yapılan bölgelerin dörtte üçü Güney Sudan hükümetinin kontrolüne geçmiştir. Bu gelişme ise Çin'in Hartum ve Juba ile ilişkilerin yeniden düzenlenmesi ihtiyacını doğurmuştur.

Sudan 2011 yılındaki referandum ile bölünmeden önce Sahraaltı Afrika'da Nijerya ve Angola'dan sonra Çin'in üçüncü büyük petrol arzı sağladığı Afrika ülkesi olmuştur. 1999-2011 yılları arasında Çin'in toplam petrol ithalatının yaklaşı \%5.5'i Sudan'dan karşılanmış ve CNPC'nin denizaşırı yatırım bölgelerindeki petrol üretiminin \%40'1 Sudan'dan sağlanmıştır (Patey, 2017, s.760). CNPC ve Sinopec'in Sudan petrol endüstrisindeki payları göz önünde bulundurulduğunda Çin'in Sudan ve Güney Sudan ile ilişkilerinin temel belirleyicisinin enerji olduğu daha net bir şekilde ortaya çıkmaktadır.

Tablo 4

Sudan ve Güney Sudan'daki Temel Petrol Şirketleri ve Şirket Hisselerinin Ülkelere Dağılımı

\begin{tabular}{|l|c|c|c|}
\hline Konsorsiyum & Şirket & Menșe Ülke & Pay (\%) \\
\hline \multirow{4}{*}{$\begin{array}{l}\text { Greater Nile Petroleum Operating } \\
\text { Company (GNPOC) }\end{array}$} & CNPC & Çin & 40 \\
\cline { 2 - 4 } & Petronas & Malezya & 30 \\
\cline { 2 - 4 } & ONGC & Sudindistan & 25 \\
\cline { 2 - 4 } & Sudapet & Güney Sudan & 5 \\
\hline \multirow{4}{*}{$\begin{array}{l}\text { Dar Petroleum Operating Company } \\
\text { (DPOC) }\end{array}$} & Nilepet & Çin & 41 \\
\cline { 2 - 4 } & CNPC & Mäney Sudan & 40 \\
\cline { 2 - 4 } & Petronas & Çin & 6 \\
\cline { 2 - 4 } & Nilepet & Misır & 3.6 \\
\cline { 2 - 4 } & Egypt Kuwait Holding & -- & 1.4 \\
\cline { 2 - 4 } & Diğer partnerler & & 5 \\
\hline
\end{tabular}




\begin{tabular}{|l|c|c|c|}
\hline \multirow{3}{*}{$\begin{array}{l}\text { Sudd Petroleum Operating Company } \\
\text { (SPOC) }\end{array}$} & Nilepet & Güney Sudan & 41.9 \\
\cline { 2 - 4 } & Petronas & Malezya & 33.9 \\
\cline { 2 - 4 } & ONGC & Hindistan & 24.1 \\
\hline \multirow{2}{*}{ Petro Energy E\&P } & CNPC & Çin & 95 \\
\hline \multirow{2}{*}{ Star Oil } & Sudanpet & Sudan & 5 \\
\cline { 2 - 4 } & Ansan Wikfs & Yemen & 66 \\
\cline { 2 - 4 } & Sudapet & Sudan & 34 \\
\hline
\end{tabular}

Kaynak: EIA, “Country Analysis Brief: Sudan and South Sudan - 2014”, s.6.

Güney Sudan, Çin’in yıllık petrol ithalatında yalnızca \%2 ile \%5 gibi bir paya sahip olsa da Güney Sudan'ın sahip olduğu politik ve jeopolitik önem Çin'in bütüncül enerji politikası kapsamında değerlendirildiğinde açıkça ortaya çıkmaktadır. Sudan özellikle Çin'in ilk denizaşırı petrol endüstrisi yatırımlarında başarı kazandığı için sembolik bir öneme sahiptir (International Crisis Group, “China’s Foreign Policy Experiment in South Sudan”, 2017, s.7). Güney Sudan'da şuanda kayıtlı yaklaşık 100 Çinli şirket enerji, mühendislik, telekomünikasyon, tıbbi hizmetler, otel, restaurant ve kiralama sektörlerinde hizmet vermektedir. Bunun doğrudan bir sonucu olarak Çin ile Güney Sudan arasındaki karşılıklı ticaret 2012 yılında 534 milyon dolar olarak gerçekleşmiştir (International Crisis Group, “China’s Foreign Policy Experiment in South Sudan”, 2017, s.8).

Çin ile Sudan arasındaki enerji ilişkisi yalnızca Çin’in arz güvenliği kapsamında değil petrol gelirlerinin Sudan ve Güney Sudan hükümet bütçelerine katkısı açısından da analiz edilmesi gerekir. Petrol ihracatının neredeyse tamamının Çin’e gerçekleştiği Güney Sudan hükümet gelirlerinin \%98'ini petrol gelirlerinin oluşturduğu düşünülürse Çin-Güney Sudan ilişkilerinin Pekin için olduğu kadar Juba için de stratejik öneme sahip olduğu ortaya çıkmaktadır. Her ne kadar Çin'in Güney Sudan ile resmi ilişkisi egemenlik, iç işlerine müdahale etmeme ve karşılıklı saygı prensiplerine dayalı olsa da Güney Sudan'ın bağımsız bir ülke olarak ortaya çıktığı koşullar Çin'in bu ülke ile ilişkilerinin özel şartlar altında oluşturulmasına yol açmıştır (Large, 2016, s.38).

Güney Sudan'daki yönetim ile 2008 gibi erken bir tarihte resmi ilişkiler kuran Pekin yönetimi bağımsızlık gerçekleşmeden önce Juba'da bir Çin Konsolosluğu açmıştır. 2011 Ocak'ta yapılan Güney'in ayrılma referandumundan sonra da Çin, Güney Sudan ile resmi diplomatik ilişkilerini 9 Temmuz 2011'de kurmuştur (Large, 2016, s.37). Bununla birlikte Güney Sudan'ın bağımsızlığı sonrasında ülkede 2011'de meydana gelen ve 2013 yılında oldukça şiddetli bir noktaya ulaşan ülke içi çatışmalar, Çin'in Güney Sudan politikasında yeni bir dönemi başlatmıştır. Mayıs 2014'de Pekin yönetimi Güney Sudan'daki BM misyonu (The United Nations Mission in South Sudan-UNMISS)'e 314 kişilik bir askerî birlik göndermiştir. İlk etapta Güney Sudan'da konuşlandırılan birlikler temel tıbbi destek, konut birimi inşası ve su sondajı gibi desteklerde bulunacak savaşmayan birlikler olmuştur. Fakat 2014 Eylül'de Çin, UNMISS'e 700 kişiden oluşan ve savaşan birliklerden oluşan ikinci bir birlik göndereceğini duyurmuştur. Bu niteliği ile Güney Sudan'daki Çinli birlikler, Çin'in barış koruma birliklerine savaşan askerî personelin gönderildiği ilk birlikler olmuştur (Benabdallah, 2016, s.27).

Bununla birlikte Liu'dan sonra Afrika ilişkileri için atanan Zhong Jianhua, arabuluculuk faaliyetlerine katılması için davet eden Hükümetlerarası Kalkınma Otoritesi 
(Intergovernmetal Authority on Development-IGAD)'ın Nairobi'deki görüşmelerine katılmıştır. 2014 ile anlaşmanın imzalandığ 2015 arasında Çin yoğun bir şekilde bu arabuluculuk faaliyetlerinde yer almıştır. Bu anlamda Güney Sudan, Çin için arabuluculuk kapasitesinin test edilip geliştirilebileceği ve anti-müdahale politikasının sınırlarının belirlenebileceği bir gerçek dünya laboratuvarıdır (International Crisis Group, "China’s Foreign Policy Experiment in South Sudan”, 2017, s.9).

Nitekim Sudan-Güney Sudan ilişkilerinin en gergin olduğu dönemde Çin, Sudan hükümetini “özel danışma toplantısı” yapılmasına ikna etmesi için Dışişleri Bakanı Wang Yi'yi görevlendirmiş ve Hartum'da Etiyopya, Sudan, IGAD ve Güney Sudan'lı tarafların katılacağı toplantı için bu ülkeleri ikna etmiştir (International Crisis Group, "China's Foreign Policy Experiment in South Sudan", 2017, s.11). Pekin, Sudan sorununda “Afrika'nın sorunlarına Afrikalı çözümler" (African solutions to African problems) ilkesi ile uzlaşma arayışlarında IGAD'ın öncü rolünü teşvik etmiştir. Batılı diplomatlar Afrika'da BM destekli kuvvetlerin yerleşmesi için Çin'in onayının Afrika bölgesel örgütlerinin onayına bağlı olduğunu farketmişlerdir (International Crisis Group, "China’s Foreign Policy Experiment in South Sudan”, 2017, s.13). Güney Sudan sorununda görüldüğü gibi Çin artık geleneksel olarak müdahale-karşııı bir ülke olarak tanımlanmayacaktır. Pekin'in küresel çıkarları yaygınlaştıkça güvenlik kaygıları da eşzamanlı olarak artmakta ve ulusal çıkarların tehdit edildiği kriz bölgelerin daha müdahaleci bir tutum sergilemektedir (Asia Centre, "Strategy of 'Parallels': China in the South Sudanese Armed Conflict", 2017, s.7).

\section{Sonuç}

Çin, yüksek ekonomik büyümenin hem sebebi hem de sonucu olarak ortaya çıkan enerji ihtiyacının sorunsuz şekilde karşılanmasını dış politikasının temel parametresi haline getirmiştir. Enerji güvenliği; diğer ülkeler için olduğu gibi Çin için de "enerji kaynaklarına yeterli erişim ve enerjiyi sorunsuz elde etme" anlamına gelse de Çin için enerji güvenliğinin sağlanması, ekonomik büyümenin devamlllı̆̆ bir şekilde ordunun güçlendirilmesi, güçlenen ordu ve ekonomi sayesinde Tayvan politikasının tavizsiz biçimde yürütülmesi ve bunların tamamının sağlayacağı Komünist Parti iktidarının devamllı̆̆ğ anlamına gelmektedir.

Rejim-Enerji bağlantısı içerisinde enerji ithalatının çeşitlendirilmesi enerji güvenliğinin en önemli parametrelerinden biridir. Bu kapsamda enerji kaynaklarını çeşitlendirmek üzere Pekin, Ortadoğu'da İran ve Suudi Arabistan'a, Orta Asya'da ise Kazakistan ve Türkmenistan'a olan bağımlılığını Afrika ile dengelemek istemektedir. Afrika kıtasının sahip olduğu enerji kaynakları, stratejik coğrafi konumu ve ekonomik gelişim için doğrudan yabancı yatırıma karşı bağımlılık seviyesinin yüksek oluşu kıtayı Çin dış politikası için hayati önemi olan bir bölge haline getirmektedir. Nitekim Kıta, Ortadoğu'dan sonra Çin'in en fazla petrol ithalatı yaptığı ikinci bölge olmuş, Çinli enerji şirketlerinin en fazla hisseye sahip olduğu bölgelerden birisi haline gelmiştir.

Çin'in Afrika'da izlediği dış politika anlayışı, Batılı güçler tarafından insan hakları ihlallerine, teröre ve savaş suçlarına destek vermekle suçlanmasına yol açmaktadır. Çin bu ülkelerdeki istikrarsızlığın bilerek yaratıldığını düşünmektedir. $\mathrm{Bu}$ ülkelere yönelik müdahaleci anlayışı yalnızca bu ülkelerin iç işlerine karışma ve bağımsızlıklarına tehdit olarak görmemekte, aynı zamanda kendisini engelleme amacı 
taşıdığını düşünmektedir. Dolayısıyla enerji elde ettiği kaynak ülkelerde yaratılan istikrarsızlığı, enerji güvenliği sorunu olarak görmektedir. Bu kapsamda Afrika'da izlenen Çin dış politikasının seyri, Pekin tarafından kabul edilen temel güvenlik, çıkar ve tehdit algılamalarını da doğrudan yansıtmaktadır.

Bunun yanında diğer taraftan Afrika ülkelerinin uzun yıllar Batılı güçler tarafından ekonomik ve siyasi sömürüye maruz kalmış olmaları bu kıtadaki yönetici elitin kendilerine destek sağlayabilecek alternatif bir güç arayışına girmelerine yol açmaktadır. Karşılıklı çıkarların buluşması Afrika ülkeleri ile Çin arasındaki ilişkileri bölgesel ve küresel politikayı etkileme kapasitesine sahip olacak seviyeye ulaştırmıştır. Nitekim Çin, 2009 yılından itibaren Afrika ülkelerinin en büyük ticari ortağı haline gelmiş, altyapı sektörüne finansal desteği sayesinde Afrika ülkelerinin yıllık ekonomik büyüme oranlarının ilk kez \% 5'in üzerinde gerçekleşmesine büyük katkı sağlamıştır.

Bunların yanında Çin'in devlet egemenliği, güç kullanımı ve müdahale karşıtlığı, iç işlere öncelik verme gibi normatif ilkeleri, Pekin yönetiminin aktif bir barış koruma destekçisi olmasını engellese de 2050 yılına kadar Çin'i küresel bir güç haline getirmeyi hedefleyen vizyon, Çin'in Afrika dış politikasını dayandırdığı ikili ilişkilerin bölgesel ve uluslararası örgütlerle iş birliğini içerecek şekilde genişletilmesini gerekli hale getirmiştir. Bu kapsamda Çin'in Afrika politikasında ön plana çıkan en önemli araçlardan bir tanesi kıtadaki bölgesel krizlerin çözümü için BM Barışı Koruma Operasyonları'na verilen aktif destek olmuştur.

BM Barışı Koruma Operasyonları'na katılım, Afrika politikası özelinde incelendiğinde Çin'in "küresel güç haline gelme" vizyonunu destekleyen bir görünüm arz etmektedir. Nitekim Çin'in BM Barışı Koruma Operasyonları'na yönelik tutumu her bölgede farklı motivasyonlar gösterse de Afrika'daki BM Barışı Koruma Operasyonları'na daha aktif şekilde katıldığı görülmektedir.

$\mathrm{Bu}$ aktifliğin en güzel örneklerinden biri Çin'in Darfur Krizi esnasında göstermiş olduğu diplomatik tutum olmuştur. Darfur Krizi’ni Sudan hükümetinin iç sorunu olarak gören Çin, bölgede herhangi bir BM Barışı Koruma Operasyonu’nun konuşlanmasına da rıza göstermemiştir. Ancak, bu tutumu sebebiyle 2008 Pekin Olimpiyatları'nın boykot edilmesi tehlikesi ile karşı karşıya kalan Çin yönetimi, 2007 yılında BM-Afrika Birliği ortak gücünün müdahale için yetkilendirilmesi kararını dönemin Sudan devlet başkanı Ömer el-Beşir'e kabul ettirmiştir.

Sudan'da 2011 yılında yapılan referandum ile Güney Sudan'ın bağımsız bir devlet olarak ortaya çıkmasında ve 2013 yılında iki devlet arasında yaşanan krizin çözümünde Çin' in arabuluculuk çabalarında aktif şekilde yer aldığı görülmektedir. Sudan krizlerinin barışçıl yollardan çözümü çabalarına Pekin yönetimi tarafından aktif şekilde destek verilmesi, Çin'in bu sayede uluslararası sistemin aktif ve "sorumlu” bir gücü olduğu imajını yaratmak istemesinden kaynaklanmaktadır. Darfur krizinden çıkacak en önemli sonuçlarından biri Pekin yönetiminin ulusal çıkarlarının gerektirdiği stratejik bölgelerde diş politika ilkelerini yeniden uyarlayabileceğini göstermesidir. Keza on yıl ara ile gerçekleşen Sudan krizleri, Pekin yönetiminin ulusal çıkarları ile uluslararası toplum tarafından kendisine yönelen yaptırımlar arasında bir denge kurmaya çalıştığını göstermesi açısından önemlidir. 
Ayrıca krizin çözümüne katkı sağlaması ve BM Barış Koruma Operasyonları'na katılım sağlamış olması, Çin'in tek stratejik kaygısının enerji olmadığını da göstermektedir. Nitekim Çin, Darfur'dan çevre ülkelere yayılacak bir istikrarsızlığın Sudan'ın komşu ülkeleri olan Etiyopya, Libya, Çad ve Orta Afrika Cumhuriyeti'nde yaptığı anlaşmaları tehlikeye sokacağını düşünmektedir.

Çin-Afrika ilişkilerinin detaylı ve çok boyutlu bir analizi, Çin'in uzak bölgelerdeki yatırım ve ticaret bağları genişledikçe Pekin yönetiminin bu bölgelerdeki istikrarsılıklara daha duyarlı hale geldiğini, istikrarsızlıkların bölgesel boyutta yayılma tehlikesi ortaya çıktığında ise iç işlerine müdahale etmeme ilkesinden taviz verebileceğini ortaya çıkarmaktadır. Pekin'in küresel çıkarları yaygınlaştıkça güvenlik kaygıları da eşzamanlı olarak artmakta ve ulusal çıkarların tehdit edildiği kriz bölgelerinde daha müdahaleci bir tutum sergilemektedir.

Hakem Değerlendirmesi: Dış bağımsız.

Çıkar Çatışması: Yazarlar çıkar çatışması bildirmemiştir.

Finansal Destek: Yazarlar bu çalışma için finansal destek almadığını beyan etmiş̧tir.

Peer-review: Externally peer-reviewed.

Conflict of Interest: The authors have no conflict of interest to declare.

Grant Support: The authors declared that this study has received no financial support.

\section{Kaynakça/References}

AFDB. (African Development Bank), African Economic Outlook (2016). Sustainable Cities and Structural Transformation, https://www.afdb.org/fileadmin/uploads/afdb/Documents/Publications/AEO_2016_ Report_Full_English.pdf, (e.t.)

Alden, C. (2005). China in Africa. Survival, 47(3), 147-164.

Alden, C., \& Alves, C. (2008). History \& 1dentity in the construction of China's Africa policy. Review of African Political Economy, 35(115), 43-58.

Ayenagbo, K., Njobvu, T., Sossou, J. V., Tozoun, B. K. (2012). China's peacekeeping operations in Africa: From unwilling participation to responsible contribution. African Journal of Political Science and International Relations, 6(2), 22-32.

Asia Centre. (2017). Strategy of 'Parallels': China in the South Sudanese Armed Conflict, s.7. file:///C:/Users/ HP/Downloads/OBS_Chine_201701-NA14-Chine\%20Sud\%20Soudan.pdf, (e.t.14.11.2017).

Benabdallah L. (2016). China's peace and security strategies in Africa: Building capacity is building peace? African Studies Quarterly, 16(3-4), 17-34.

Burgos, S., \& Ear, S. (2012). China's Oil Hunger in Angola: history and perspective. Journal of Contemporary China, 21(74), 351-367.

BP, Statistical Review of World Energy June 2017, http://www.bp.com/content/dam/bp/en/corporate/pdf/ energy-economics/statistical-review-2017/bp-statistical-review-of-world-energy-2017-full-report.pdf, (e.t. 07.09.2017).

Campbell, H. (2008). China in Africa: Challenging US global hegemony. Third World Quarterly, 29(1), 89-105.

Cheng-Joseph, Yu-S., Shi, H. (2018). China's African policy: Increasing importanceand active adjustments. Multilateral Approach in China's Foreign Policy, World Scientific Publishing, 587-645.

China Daily. (2018). China Keeps Up UN Peacekeeper Role. 16.05.2018, http://www.chinadaily.com. $\mathrm{cn} / \mathrm{a} / 201805 / 16 / \mathrm{WS} 5 \mathrm{afc} 2 \mathrm{f5} 4 \mathrm{a} 3103 \mathrm{f6866ee} 8 \mathrm{c} 87 . \mathrm{html}$ (e.t. 20.02.2019)

Cho, S. (2018). China's participation in UN peacekeeping operations since the 2000s. Journal of Contemporary China, 1-17.

Courtney, J. F. (2016). China's Troop Contributions to U.N. Peacekeeping. 26 July, 2016. United States Institutes of Peace, https://www.usip.org/publications/2016/07/chinas-troop-contributions-un-peacekeeping (e.t. 16.07.2018).

Csis, E. A. (2017). China in Africa. https://www.cfr.org/backgrounder/china-africa, e.t. 06.09.2017.9).

Dahir, A. L. (2019). Africa's resource-rich nations are getting even more reliant on China for their exports. Quartz Africa, April 26, 2019. https://qz.com/africa/1605497/belt-and-road-africa-mineral-rich-nationsexport-mostly-to-china/, (e.t.09.11.2019). 
Department of the Secretary of State (2018). Military and Security Developments Involving the Peaople's Republic of China. Annual Report to Congress, USA.

Doğan, F. (2017). Çin ’in hegemonik yükselişi, Pax Americana'dan Pax Sinica 'ya. Ankara: Orion Kitabevi.

Dollar, D. (2017). China's Engagement with Africa, from Natural Resources to Human Resources, 2016, https://www.brookings.edu/wp-content/uploads/2016/07/Chinas-Engagement-with-Africa-David-DollarJuly-2016.pdf, (e.t. 06.09.2017).

EIA. (2014). Country Analysis Brief: Sudan and South Sudan.

Ekengard, A. (2008). The African Union Mission in SUDAN (AMIS), Experiences and Lessons Learned. FOI (Swedish Defence Research Agency), Stockholm.

Fang, S., \& Sun, F. (2019). Gauging Chinese public support for China's role in peacekeeping. The Chinese Journal of International Politics, 179-201.

FOCAC. Chinese Diplomatic Missions in Africa, http://www.focac.org/eng/xglj/zfsg/

Gamache, L., \& Hammer, A., Jones, L. (2013). China's Trade and Investment Relationship with Africa. USITC Executive Briefings on Trade, April 2013, https://www.usitc.gov/publications/332/2013-04_ChinaAfrica(GamacheHammerJones).pdf, (e.t. 09.11.2019).

Gilboy, G. J., \& Heginbotham, E. (2012). Chinese and Indian Strategic Behaviour Growing Power and Alarm. New Delhi: Cambridge University Press.

Hanuer, L., \& Morris, L. J. (2014). Chinese Engagement in Africa: Drivers, Reactions, and Implications for U.S. Policy. RAND Corporation, file://C:/Users/HP/Downloads/RAND_RR521.pdf, (e.t. 11.11.2019).

He, Y. (2007). China's Changing Policy on UN Peacekeeping Operations. Institute for Security and Development Policy, Sweden.

He, Y. (2018). China rising and its changing policy on UN peacekeeping. United Nations Peace Operations in a Changing Global Order, (Eds. Cedric de Coning ve Mateja Peter), Palgrave MacMillan, Switzerland.

Holslag, J. (2008). China's diplomatic manoeuvring on the question of Darfur. Journal of Contemporary China, 17(54), 71-84.

Holslag, J. (2009). China’s new security strategy for Africa. Parameters, 39(2), 23-37.

Ighobor, K. (2013). China in the heart of Africa. UN Africa Renewal, https://www.un.org/africarenewal/ magazine/january-2013/china-heart-africa, (e.t.08.11.2019).

International Crisis Group. (2017). China’s Foreign Policy Experiment in South Sudan”, 10 July 2017, https://d2071 andvip0wj.cloudfront.net/288-china-s-foreign-policy-experiment-in-south-sudan.pdf, (e.t. 13.11.2017).

International Energy Agency IEA. (2017). Africa Energy Outlook, 2014, https://www.iea.org/publications/ freepublications/publication/WEO2014_AfricaEnergyOutlook.pdf

ISDP. (2018). Institute for Security and Development, (2018). "China's Role in UN Peacekeeping", March 2018.

Karaca, R. K. (2011). Powers in the Chaging System After the Cold War (USA, EU, China and Russia), Partnership for Peace Review, 2(2), 77-100.

Karaca, R. K. (2012). Çin'in değişen enerji stratejisinin dış politikasına etkileri (1990-2010). Uluslararası İlişkiler. 9(33), 93-118.

Kazeem, Y. (2017). China doubled its investment spend in Africa in 2016 as US and UK fell. https:/qz.com/ africa/978419/china-influence-has-an-investor-in-africa-grew-in-2016/, (e.t. 08.11.2019).

Lantergne, M. (2018). The role of UN peacekeeping in China's expanding strategic interests. United States Institute of Peace-USIP. https://www.usip.org/sites/default/files/2018-09/sr_430_lanteigne_final.pdf, (e.t. 09.11.2019).

Large, D. (2016). China and South Sudan's civil war, 2013-2015. African Studies Quarterly, 16(3-4), 35-54.

Masuda, M. (2011). China's Peacekeeping Diplomacy and Troop Dispatch: A New Avenue for Engagement with the International Community. http://www.nids.mod.go.jp/english/publication/kiyo/pdf/2011/bulletin e2011_2.pdf, (e.t. 16.07.2018).

Matsuda, Y. (2016). China's UN Peacekeeping Operations Policy: Analysis of the Factors behind the Policy Shift toward Active Engagement. http://www2.jiia.or.jp/en/pdf/digital_library/china/160331_Yasuhiro_ Matsuda.pdf (e.t. 16.07.2018)

MOD (Ministry of National Defence). China Grows Presence of UN Peacekeeping Missions Abroad. http://eng. mod.gov.cn/news/2018-02/28/content_4809003.htm, 28.02.2018. (e.t. 20.02.2019).

Patey, L. (2017). Learning in Africa: China's overseas oil investments in Sudan and South Sudan. Journal of Contemporary China, 26(107), 756-768.

Payne, R. J., \& Veney, C. R. (1998). China's post-cold war African policy. Asian Survey, 38(9), 867-879.

Pauley, L. (2018). China Takes the Lead in UN Peacekeeping. The Diplomat, 17 April, 2018. https://thediplomat. com/2018/04/china-takes-the-lead-in-un-peacekeeping/ (e.t. 16.07.2018)

Shambaugh, D. (2016). Çin Küreselleşme Yolunda (Çev. Latif Boyac1). İstanbul: Yarın Yayınları.

Shinn, D. H. (2006). China and the Conflict in Darfur. Brown Journal of Affairs, 16(1), 85-100.

SIPRI (2019). TIV of arms exports to Sudan, 2010-2018. http://armstrade.sipri.org/armstrade/html/export values.php, (e.t. 09.11.2019). 
Stähle, S. (2008). China's shifting attitude towards united nations peacekeeping operations. China Quarterly, 195, 631-655.

Strauss, J. C., \& Saavedra, M. (2009). Introduction: China, Africa and internationalization. The China Quarterly, 199, 551-562.

Süöer, G. (2010). Dış politikada süreklilik-değişim çekişmesi. Uluslararası Hukuk ve Politika, 6(23), $73-98$.

Taylor, I. (1998). China's foreign policy towards Africa in the 1990s. The Journal of Modern African Studies, $36(3), 443-460$.

Tull, D. M. (2006). China's engagement in Africa: scope, signifacance and consequences. Journal of Modern African Studies, 44(3), 459-479.

Tüter, M. (2018). Çin gücü, statükoya karşı yeni güç arayışları. İstanbul: Kopernik Yayınevi

Zhao, S. (2014). A neo-colonialist predator or development partner? China's engagement and rebalance in Africa. Journal of Contemporary China, 23(90), 1033-1052.

UNPKO. (2017). https://peacekeeping.un.org/en, (e.t.15.11.2017).

UNPKO. (2008). United Nations Peacekeeping Operations Principles and Guidelines. Capstone Doctrine. https://peacekeeping.un.org/sites/default/files/peacekeeping/en/capstone_eng.pdf (e.t. 21.02.2019).

Üngör, Ç. (2009). Çin ve üçüncü dünya. İ.̈̈. Siyasal Bilgiler Fakültesi Dergisi, 41, 27-38.

Vasquez, P. I., (2019). China's oil and gas footprint in Latin America and Africa. International Development Policy. https://journals.openedition.org/poldev/3174, (e.t. 09.11.2019).

Wang, F. L., \& Elliot, E. A. (2014). China in Africa: presence, perceptions and prospects. Journal of Contemporary China, 23(90), 1012-1032.

WB (World Bank). (2017). Wits, Sub-Saharan Africa Trade Summary 2015 Data, http://wits.worldbank.org/ CountryProfile/en/Country/SSF/Year/LTST/Summary, (e.t. 06.09.2017).

WB (World Bak). (2017). World Development Indicators 2017.

WTO (World Trade Organization) (2016). World Trade Statistical Review. https://www.wto.org/english/res_e/ statis_e/wts2016_e/wts2016_e.pdf, (e.t. 06.09.2017).

China-Africa Economic and Trade Cooperation (2013). http://english.gov.cn/archive/white_paper/2014/08/23/ content_281474982986536.htm, (e.t.07.09.2017).

Zurcher, C. (2019). 30 Years of Chinese Peacekeeping. Centre for International Policy Studies (CIPS), University of Ottawa, https://www.cips-cepi.ca/wp-content/uploads/2019/01/30YearsofChinesePeacekeepi ng-FINAL-Jan23-1.pdf, (e.t. 11.11.2019). 